\title{
EL FUTURO ESTÁ EN LA COMEDIA ROMÁNTICA DE HOLLYWOOD: LAS CHICAS MODERNAS DE MANUEL ROMERO
}

The Future is in Hollywood Romantic Comedy: Manuel Romero's Modern Girls

IVÁN MORALES ${ }^{\mathrm{a}}$

Universidad de Buenos Aires / CONICET

DOI: $10.15366 /$ secuencias2021.53.005

\begin{abstract}
RESUMEN
En este artículo estudio un grupo de películas realizadas por Manuel Romero entre 1938 y 1942, donde se apropió de la comedia romántica hollywoodense para incorporar al cine argentino la figura de la chica moderna. Cercana a la heroína indisciplinada de la screwball comedy (un género que, justamente, se destaca por tener a mujeres independientes como protagonistas), la chica moderna romeriana posee un carácter desestabilizador que le permite alterar las lógicas de clase, género e identidad nacional prefijadas, moviéndose con libertad entre ricos y pobres, hombres y mujeres, costumbres argentinas y cosmopolitas.
\end{abstract}

Palabras clave: comedia romántica, chica moderna, género y clase, cine argentino.

\begin{abstract}
In this article, I study a group of films directed by Manuel Romero between 1938 and 1942 where he appropriated Hollywood romantic comedy to incorporate the figure of the modern girl into Argentine cinema. Close to the unruly heroine of the screwball comedy (a genre that, precisely, stands out for having independent women as protagonists), the modern girl of Romero has a destabilizing personality that allows her to alter fixed roles of class, gender, and national identity, moving herself freely among rich and poor, men and women, Argentine and cosmopolitan customs.
\end{abstract}

Keywords: romantic comedy, modern girl, gender and class, Argentine cinema.

[a] Iván Morales es Doctor en Historia y Teoría de las Artes por la Universidad de Buenos Aires. Actualmente se desempeña como Becario Posdoctoral del Consejo Nacional de Investigaciones Científicas y Técnicas y desarrolla sus investigaciones en el Centro de Investigación y Nuevos Estudios sobre Cine (Instituto de Historia del Arte Argentino y Latinoamericano, UBA). E-mail: ivanmorales@gmail.com 


\section{Introducción}

El 29 de mayo de 1935 la compañía teatral de Manuel Romero estrenó la revista ;El provenir está en Hollywood!... en el teatro Porteño. El título era ambiguo. Los puntos suspensivos ponían un manto de duda sobre la afirmación entusiasta entre signos de admiración. La «fantasía revisteril», como la definía el programa, narraba el viaje a Hollywood de cuatro criollos que pretenden vender un guion cinematográfico a productores extranjeros. Un argumento ideal para que Romero satirizara dos cuestiones comunes por esos tiempos: los artistas y periodistas que salían del país a buscar éxito en la meca del cine y la manera en que Hollywood retrataba a Latinoamérica. El primer encuentro de los protagonistas con el mundo de las estrellas parece prometedor. Al llegar asisten a un prestigioso nightclub de Los Ángeles - el Cocoanut Grove- y conocen a las celebridades cinematográficas del momento (Greta Garbo, Jean Harlow, Katherine Hepburn, Charles Chaplin, Mae West, John Barrymore, todas interpretadas por actores locales); sin embargo, a la hora de conseguir trabajo solo logran un papel como extras en una típica película para el mercado hispanohablante. La crítica del diario Noticias Gráficas señalaba la justeza de la sátira: «con buen humor se comenta la impresión de un cuadro 'criollo' que no ha de distar mucho, por cierto, de la realidad, si hemos de atenernos a las impresiones que se derivan de los films que nos llegan de Hollywood o Joinville...». Romero se burlaba con dureza de las ideas exóticas que Hollywood tenía de la geografía y la cultura latinoamericana. Tal es así que varias crónicas subrayaron el excesivo encono contra Estados Unidos: «no pondremos punto final a esta crónica sin destacar la conveniencia que habría en suprimir toda alusión hiriente para un país que acaba de darnos muestras de su cordialidad y su simpatía»${ }^{\text {. }}$

Eran los años de la «política del buen vecino» y quizás por eso la prensa miraba con otros ojos los gestos «antiyanquis» de este estilo ${ }^{2}$. Pero no era la primera vez que Romero aludía en clave cómica al universo de Hollywood desde la revista porteña, un género teatral que se caracterizaba por incorporar las novedades del presente. Así como había parodiado la aparición del sonido en Las burlas del film sonoro (1930), ahora lo hacía con los nuevos vínculos entre Hollywood y Latinoamérica propiciados por el fugaz mercado de películas hispanohablantes, una experiencia que Romero conocía de cerca porque, como muchos otros latinos, su ingreso al universo cinematográfico fue en los estudios que Paramount poseía en Joinville. ${ }^{3}$

Pocos meses después del estreno de ¡El porvenir está en Hollywood!..., Romero debutó en la industria local con Noches de Buenos Aires (1935) y de allí en adelante se convirtió no solo en el director más prolífico del joven cine sonoro argentino sino también en un gran promotor de la cultura popular nacional. El mundo del tango, el arrabal, la noche porteña, el turf, la radio, el teatro y la calle Corrientes dominaron sus primeros trabajos. Pero hacia 1938, inspirado en la comedia romántica hollywoodense de los años treinta — conocida como screwball comedy - Romero comenzó a abordar el mundo de los ricos incorporando al cine argentino la impredecible heroína característica del género. El título de aquella obra de teatro, entonces, adquiría otro sentido. Quizás el porvenir sí estaba en Hollywood, pero no era necesario que los cineastas locales viajaran al exterior a buscar un éxito improbable, sino que integraran las tendencias y fórmulas del cine internacional a la producción local.

Esto no quiere decir que Romero abandonara la aversión burlona hacia la cultura extranjera y las elites locales. De hecho, el romance interclasista típico de la screwball comedy, introducido por primera vez en La rubia del camino (Manuel Romero, 1938),
[1] Noticias Gráficas, 30 de mayo 1935 .

[2] La llegada de Franklin D. Roosevelt a la presidencia de Estados Unidos en 1933 trajo la «política del buen vecino» con la que se intentó aplacar la «yanquifobia» en América Latina. Véase Leandro Morgenfeld, Vecinos en conflicto. Argentina y Estados Unidos en las Conferencias Panamericanas (1880-1955) (Buenos Aires, Continente, 2011). El cronista del diario probablemente se refería a algún episodio de la reciente Conferencia Comercial Panamericana iniciada el 26 de mayo en Buenos Aires. No obstante, la relación entre ambos países nunca dejó de ser conflictiva. Tan solo un año después, la visita de Roosevelt sería recordada por la irrupción del hijo del presidente argentino, Liborio Justo, al grito de « Abajo el imperialismo yanqui!».

[3] En estos estudios norteamericanos localizados en Francia y destinados a filmar en diversos idiomas, Romero dirigió $L a$ pura verdad (1931) y ¿Cuándo te suicidas? (1932), y junto a Bayón Herrera escribió el guion de Las luces de Buenos Aires (Adelqui Millar, 1931), la película internacional, pero de ambiente criollo, que lanzó a Carlos Gardel al estrellato. 
[4] Matthew Karush, Cultura de clase. Radio y cine en la creación de una Argentina dividida (19201946) (Buenos Aires, Ariel, 2013), p. 214.

[5] Cecilia Tossounian, La Joven Moderna in Interwar Argentina: Gender, Nation, and Popular Culture (Gainesville, University of Florida Press, 2020). El libro de Tossounian es fundamental para comprender el surgimiento y desarrollo de la figura de la joven moderna en Argentina y su expresión en distintos medios (folletines, revistas, películas, concursos de belleza, historietas, publicidades). era un medio ideal para ello. Como afirma Karush en su agudo análisis sobre esta película, en el cine de Romero «la oposición entre los ricos y los pobres se articulaba como oposición entre lo extranjero y lo nacional [...] su premisa era la expulsión de los ricos». ${ }^{4}$ Sin embargo, esta oposición radical entre la cultura popular nacional y los gustos extranjerizantes de la clase alta, que quizás fuera cierta para La rubia del camino, no estuvo exenta de ambigüedades y tensiones a lo largo de su filmografía, sobre todo si se considera que estos gestos nacionalistas se apoyaban en estructuras narrativas y en heroínas de películas hollywoodenses de las que también disfrutaba el público masivo. Las audiencias locales ¿asistían a ver el triunfo de los pobres nacionales frente a los ricos extranjeros y de la tradición sobre la modernidad? ¿O iban a disfrutar de las ideas modernas, los nuevos modelos de feminidad, los diálogos mordaces y el ritmo acelerado que traían estas nuevas comedias? Probablemente ambas respuestas sean afirmativas. Así como en La rubia del camino — basada en Sucedió una noche (It Happened One Night, Frank Capra, 1934) - una chica moderna y europeizada aprende a ser auténticamente argentina despojándose de los vicios de su clase y entregándose al amor de un hombre del pueblo; tan solo cuatro años después, en Elvira Fernández, vendedora de tienda (1942) —basada en El diablo burlado (The Devil and Miss Jones, Sam Wood, 1941)-, otra chica moderna formada en Estados Unidos motoriza las conquistas laborales de una multitud de trabajadoras en huelga. ¿Cómo leer estos dos extremos?

En este artículo abordaré un ciclo de películas — La rubia del camino, Mujeres que trabajan (1938), La modelo y la estrella (1939), Muchachas que estudian (1939), Isabelita (1940), Un bebé de París (1941), Mi amor eres tú (1941), Elvira Fernández, vendedora de tienda - en el que Romero se apropió de la comedia romántica hollywoodense para introducir la figura de la chica moderna, un modelo de feminidad que había florecido en la Buenos Aires de los años veinte y treinta con el crecimiento de la vida urbana, la circulación de modas internacionales, la aparición de nuevos comportamientos sexuales y amorosos y la expansión de la cultura de masas. ${ }^{5}$ Cercana a la heroína indisciplinada de la screwball comedy (un género que, justamente, tiene a mujeres independientes como protagonistas) la chica moderna romeriana presenta un carácter desestabilizador que le permite alterar las lógicas de clase, género e identidad nacional prefijadas, moviéndose con libertad entre ricos y pobres, hombres y mujeres, costumbres argentinas y cosmopolitas. Pero esta capacidad para alterar el orden también la convierte en un sujeto peligroso a domesticar.

Aun con sus ambivalencias, Romero otorgó un protagonismo inédito a los personajes femeninos en la pantalla nacional. En este ciclo de comedias, hay mujeres que trabajan, que estudian, que se divierten, que desafían a sus novios, padres y patrones, que plantean nuevos tipos de vínculos amorosos y que se organizan para ayudarse mutuamente. Si Romero, atento a las novedades de la industria cultural, apeló una y otra vez al cine de Hollywood no solo fue porque este le proveía formas y estructuras narrativas adaptables a la industria cinematográfica naciente, sino también porque en la screwball comedy encontró un medio óptimo para interpretar y elaborar cinematográficamente una serie de cambios y ansiedades culturales vinculados con los nuevos roles que estaban adquiriendo las mujeres en la sociedad.

\section{Una nueva estrella para un nuevo género}

El estreno de La rubia del camino tuvo un impacto especial en la recepción crítica. Resultaba absolutamente familiar al ponerla en serie con las comedias que llegaban de 
Hollywood, pero, a la vez, era única en su género si se la comparaba con la producción nacional. Roland, quien se encargaba de los estrenos nacionales en el diario Crítica, escribió una nota elocuente del particular efecto que causó la película:

La rubia del camino es una película norteamericana cien por ciento. De ritmo norteamericano. De presentación norteamericana. De estructura norteamericana. Y hasta de espíritu norteamericano. Una película que calca los valores del cine norteamericano. Y los reproduce a través de una versión bien argentina. [...] La rubia del camino es la primera comedia fina del cine argentino [...] una obra exactamente encuadrada dentro de los moldes típicos del género. Que son los moldes más concordantes con el gusto del público. Un gusto a base de refinamiento implantado por la escuela de los buenos maestros del humorismo cinematográfico: Capra, Leo McCarey, Wesley Ruggles. ${ }^{6}$

¿Cómo una producción argentina, y especialmente una de Romero, podía ser «una película norteamericana cien por ciento»? En una versión adaptada a la alta burguesía criolla, Betty (Paulina Singerman) es creada a semejanza de Ellie (Claudette Colbert), la protagonista de Sucedió una noche. Ambas caprichosas y millonarias, desobedeciendo el mandato paterno, escapan del ambiente lujoso en el que se encuentran (un yate en la versión norteamericana y el hotel Llao-Llao en la argentina) e inician una travesía por el interior de sus países. Durante el viaje conocen a un hombre de otra clase social de quien se enamoran no sin antes superar una serie de obstáculos que enfrentarán duramente a la pareja. En 1938 la screwball comedy estaba en su apogeo y Romero tenía un amplio abanico de opciones sobre las que inspirarse. Sin embargo, el romance interclasista de Sucedió una noche y su estructura de viaje le permitía adaptar la historia al contexto local combinando el mundo rural popular con la irrupción de la rebelde joven moderna. El término «screwball» provenía del baseball y se usaba para definir un tipo de lanzamiento errático que buscaba confundir al bateador. Los críticos cinematográficos norteamericanos lo adoptaron tempranamente para hablar de un novedoso estilo de comedia romántica en el cual la pareja protagonista - pero sobre todo la heroína - era verdaderamente impredecible y en el que predominaba cierta «confusión sobre el romance y las relaciones humanas» ${ }^{7}$. En la screwball comedy raramente hay gestos románticos, existe más bien una inédita combinación de sofisticación y sagacidad verbal, tensión sexual, violencia física e inversión de roles. Su particularidad, además, es que el verdadero motor de la acción y quien inicia la conquista es la mujer.

Si hasta el momento la producción cinematográfica nacional relacionada con el género cómico tenía sus raíces en la comedia popular teatral —el sainete, la revista porteña y las actuaciones de cómicos del estilo de Luis Sandrini, Pepe Arias y Florencio Parravicini-, La rubia del camino representó un cambio abrupto no solo vinculado con el mundo retratado sino también con el tipo de protagonista que necesitaba una obra de este estilo. ¿Dónde encontrar una actriz que pudiera encarnar un personaje similar al que hacía Claudette Colbert, quien combinaba elementos de la comedia sofisticada y del slapstick? Roland no casualmente dedicó la segunda parte de su crítica a una descripción entusiasta del debut cinematográfico de la protagonista: «El triunfo de Manuel Romero debe ser compartido. Ha contado con un valor primordial para dar categoría a La rubia del camino. [...] Paulina Singerman se ha limitado a aportar al cine su personal experiencia escénica. Esto sería contraproducente para otra actriz teatral [...] Pero en Paulina Singerman no es teatro. Es cine» ${ }^{8}$.
[6] Roland, «Buenos valores cinematográficos tiene el film de Romero La rubia del camino» (Crítica, 7 de abril de 1938), s/d.

[7] Ed Sikov, Screwball: Hollywood's Madcap Romantic Comedies (Nueva York, Crown Publishers, 1989), p. 19.

[8] Roland, «Buenos valores cinematográficos tiene el film de Romero La rubia del camino» (Crítica, 7 de abril de 1938), s/d. 
[9] Frank Capra, The Name above the Title (Nueva York, Macmillan, 1971), p. 183.

[10] Singerman, además, venía adaptando comedias sofisticadas contemporáneas e internacionales como Strictly Dishonorable escrita por Preston Sturges para Broadway y luego llevada a Hollywood.

[11] «¿Resolverá Paulina la gran incógnita?» (Cine Argentino, ${ }^{\circ}$ 1,12 de mayo de 1938), s/d.

[12] «Paulina Singerman. La 'fierecilla' de Shakespeare, pero sin domar...» (Cine Argentino, ${ }^{\circ} 16$, 25 de agosto de 1938), s/d.

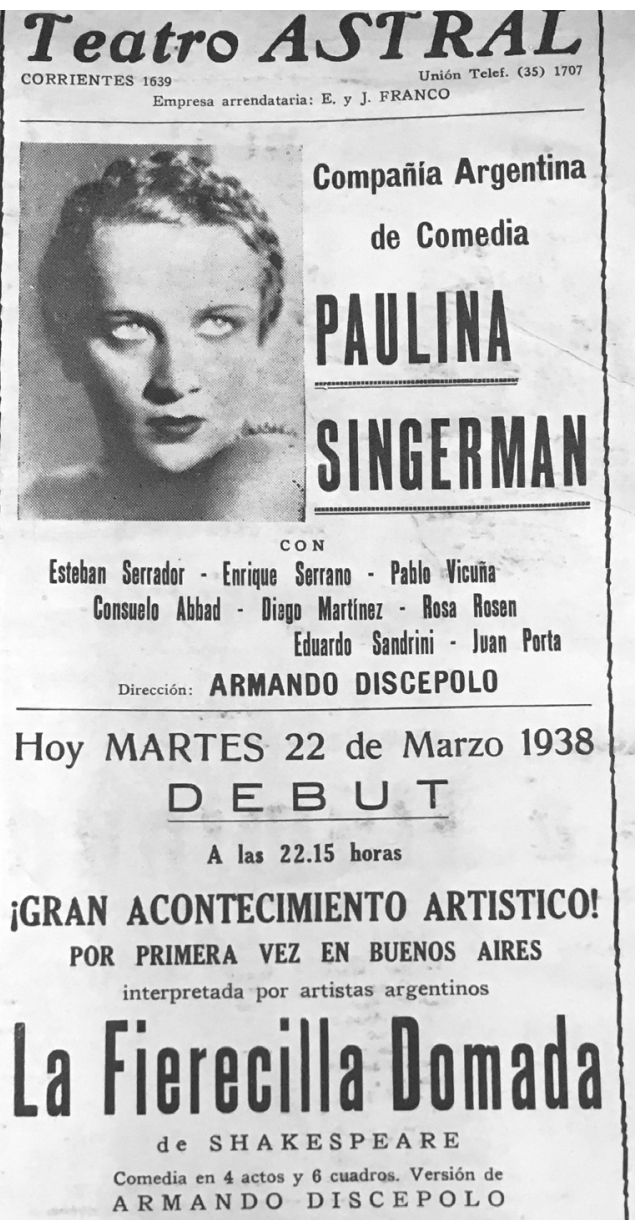

Publicidad del estreno de La fierecilla domada, a cargo de la Compañía Argentina de Comedia Paulina Singerman.
Pocas semanas antes de la aparición de La rubia del camino, la Compañía Teatral de Comedia Paulina Singerman estrenó La fierecilla domada de William Shakespeare en el Teatro Astral. Los espectadores porteños habían visto esta obra llevada a cabo por extranjeros, pero nunca interpretada por actores argentinos. El programa de la obra destacaba en primer plano la importancia del suceso para el campo teatral, aunque habría que agregar también su relevancia en el campo cinematográfico. Distintos críticos e historiadores de la screwball comedy coinciden en que la comedia shakesperiana y la trama de la «batalla de los sexos» que la caracteriza están en la base del género. E incluso el propio Capra cuenta en su autobiografía que La fierecilla domada le fue sugerida por su editor al momento de escribir el guion de Sucedió una noche con el fin de diseñar la relación entre Ellie y Peter a la manera en que Shakespeare lo hizo con Kate y Petrucchio, donde la mujer incontrolable e indisciplinada es domada por el único hombre capaz de manejarla ${ }^{9}$. Romero, entonces, no solo adaptó la historia de Capra e identificó sus fuentes sino también recurrió a las nuevas expresiones del teatro nacional para buscar una actriz sin experiencia cinematográfica pero cuyos personajes sintonizaban con las heroínas de la comedia romántica de Hollywood. ${ }^{10}$

Estos flujos de textos, imágenes y estilos de actuación que comenzaron a atravesar a una industria cultural local cada vez más transnacional causaron sin embargo cierta sensación dislocada respecto de la identidad de la actriz. Cuando se estrenó La rubia del camino, Cine Argentino — revista clave del período que acompañó al auge de la cinematografía nacional- reprodujo en su primer número una conversación entre dos mujeres al salir del cine. Una de ellas decía sobre el personaje de Singerman: «hay que reconocer que es graciosa, desenvuelta, una verdadera estrella de esas de películas americanas... A mí, te juro, que me parecía raro que no hablara en inglés... Estaba deliciosa...». ${ }^{11}$ Pero si bien la evaluación de las espectadoras era positiva, este nuevo modelo de heroína que remitía a un tipo foráneo fue puesto en entredicho por la misma revista en un intento de encontrarle rasgos nacionales a una actriz quizás demasiado cosmopolita, un paso necesario en el proceso de constitución de estrellas autóctonas que estaba encarando la industria nacional y en el cual las publicaciones del rubro jugaban un papel fundamental. Así, el pelo rubio y la caracterización de joven caprichosa que arrastraba del teatro y del cine fueron matizados por Cine Argentino atribuyéndole actitudes que serían más propias de la morocha argentina: «a pesar de ser rubia, Paulina es fuerte, apasionada e impetuosa como una morena... En apariencia es la verdadera 'Fierecilla' de Shakespeare, pero sin domar...». ${ }^{12}$

Aunque la revista intentó nacionalizar a la nueva rubia del cine argentino cuyo color de pelo podía poner en duda su nacionalidad y su carácter, lo cierto es que el personaje de Singerman en La rubia del camino estaba 
inspirado en actrices de la comedia romántica de Hollywood (Claudette Colbert, Carole Lombard, Jean Arthur, Katherine Hepburn, entre otras) quienes, lejos de encarnar simplemente a rubias/blancas frívolas y malcriadas, trajeron un nuevo tipo de mujer a la pantalla. Sus personajes podían ser aniñados, alocados y exageradamente lúdicos, pero esto no implicaba debilidad y sumisión sino, por el contrario, indisciplina frente a la autoridad de los hombres (padres y novios) y una sexualidad ambivalente (ni vírgenes ni vampiresas) aunque afirmativa. ¿Hasta qué punto el cine argentino se permitió adaptar un personaje con esta clase de rebeldía?

\section{La chica moderna ;domada?}

La unruly woman, como la definió Kathleen Rowe, es una figura histórica de la transgresión femenina que encontró un lugar ideal para manifestarse en la comedia romántica de los años treinta. Este género, dice Rowe, «demanda un lugar para la mujer» y tiene un carácter antiautoritario que se burla del heró́smo masculino ${ }^{13}$. A diferencia de la femme fatale, su sexualidad no es incontrolable ni perversa, pero tampoco santificada o negada como sucede con la virgen/madonna. Más bien se encuentra en un estado liminal y allí reside su poder. En Sucedió una noche, donde esta figura adquirió forma cinematográfica por primera vez, Ellie escapa del control del padre pero todavía no está bajo el control de otro hombre; ya no es una niña pero tampoco es una esposa o una madre; y si bien Peter (Clark Gable), su enamorado, la trata constantemente de «mocosa», ella es capaz de lograr que un tipo duro como él, dispuesto a darle lecciones de vida sobre diversos tópicos, le prepare el desayuno vestido con un delantal en una curiosa inversión genérica. Es que en el núcleo de Sucedió una noche está la construcción de una pareja que, pese a la intensa batalla verbal y física basada en profundas diferencias de clase y género, apunta hacia un modelo de igualdad en el cual la mujer reclama el reconocimiento de su deseo. Así como Ellie está dispuesta a despojarse de sus privilegios después de haber atravesado los Estados Unidos del contexto de la Depresión y a renunciar a su aristocrático esposo, Peter tiene que dejar de lado sus prejuicios hacia la joven millonaria y su impostura de macho aleccionador. En esta comedia clase y género están íntimamente imbricados y la que altera sus límites es la heroína indisciplinada.

Aunque Romero adaptó el romance interclasista y la trama del descubrimiento del mundo de los pobres por parte de la alocada millonaria, y encontró en la figura de la chica moderna porteña un modelo ideal para reproducir la energía subversiva de la unruly woman; la equidad en la dinámica de la pareja lograda por Capra y por otros directores que profundizaron esta cuestión ${ }^{14}$ pareciera inadaptable a la cosmovisión que predominaba en el cine argentino de los años treinta y, sobre todo, a sus figuras masculinas. Una primera causa puede encontrarse en la falta de modelos actorales que estuvieran a la altura de las mujeres que interpretó Singerman. Como ha señalado María Valdez, en La rubia del camino «ella es la clave para destornillar la comedia y no su partenaire de turno, demasiado desgarbado (como figura corporal, como cadena significante) y un tanto lento a la hora de devolver el ágil discurrir de la muchacha» ${ }^{15}$. Pero esta disparidad no descansa solamente en una deficiencia actoral, sino también en diferencias fundamentales en la construcción ideológica de los hombres en las comedias de Romero poco propensos a poner en juego su masculinidad como lo hicieron Clark Gable, Cary Grant o William Powell. ${ }^{16}$

En la primera apropiación local de la heroína de la screwball comedy, la im-
[13] Kathleen Rowe, The Unruly Woman: Gender and the Genres of Laughter (Austin, University of Texas Press, 1995), p. 102.

[14] Al servicio de las damas (My Man Godfrey, Gregory La Cava, 1936), La fiera de mi niña (Bringing Up Baby, Howard Hawks, 1938), La picara puritana (The Awful Truth, Leo McCarey, 1937) son algunos de los ejemplos canónicos.

[15] María Valdez, «El reino de la comedia: un terreno escurridizo y ambiguo», en Claudio España (dir.), Cine Argentino. Industria y clasicismo. Volumen II (Buenos Aires, FNA, 2000), p. 287.

[16] Por supuesto, esto también está relacionado con los procesos de modernización específicos de cada sociedad, a los que me referiré más adelante. 
[17] Matthew Karush, Cultura de clase, p. 219.

[18] Para una extensa lectura sobre los significados del muro (virginidad, sexualidad, transgresión, Código Hays) y una reconstrucción de las interpretaciones críticas que ha recibido, véase Linda Mizejewski, It Happened One Night (Malden, Wiley-Blackwell, 2010).

[19] Tina Olsen Lent, «Romantic Love and Friendship: The Redefinition of Gender Relations in Screwball Comedy», en Kristine Brunovska Karnick y Henry Jenkins (eds.), Classical Hollywood Comedy (Nueva York, American Film Institute, 1995), p. 326.

[20] Kathrina Giltre, Hollywood Romantic Comedy: States of the Union, 1934-1965 (Manchester, Manchester University Press, 2006), p. 56. bricación entre clase y género posee una inflexión diferente a la de Sucedió una noche ya que tiende a contener los impulsos de independencia de la mujer afirmando la autoridad del hombre y acomodándolos a sus expectativas. La indisciplina de la protagonista de La rubia del camino es reencausada a través del discurso de la maternidad, aplacando cierta potencialidad disruptiva y contaminando el modo narrativo dominante - la comedia - con un atributo típico del melodrama. Karush da en la clave cuando compara la construcción de la feminidad de Ellie en Sucedió una noche con la «bastante menos atrevida» feminidad de Betty en La rubia del camino. ${ }^{17}$ En cada película hay un momento bisagra que cambia el vínculo entre la pareja, pero mientras que en la película de Capra ese cambio está ligado al reconocimiento mutuo del deseo sexual, en la de Romero consiste en el descubrimiento del instinto maternal. La famosa escena de la habitación del hotel de Sucedió una noche donde Ellie deja de ser representada como una mera millonaria caprichosa y empieza a ser considerada como una mujer adulta y sexualmente activa, tiene su curioso equivalente local en la escena donde Betty ayuda a una mujer a parir. Cuando los personajes llegan a la casa del amigo italiano y se enteran de que su esposa está a punto de dar a luz, Betty se siente interpelada ante la sentencia de Julián en la que dice «hay una mujer, pero es como si no lo hubiera», y decide hacerse cargo. Romero desexualiza la muralla construida con una soga y una manta que separaba las dos camas en Sucedió una noche y las convierte en una cortina divisoria de un espacio sagrado. ${ }^{18}$ Lo que era un muro de contención de las tensiones sexuales aquí es reemplazado por un ritual ligado a la maternidad y en el que se pone en juego la feminidad de Betty. De ahí que Betty primero le diga a Julián «venga, ayúdeme» y luego se corrija: «ah no, es cierto que usted no puede entrar». En la composición formal de la escena de Sucedió una noche, Ellie y Peter compartían el mismo espacio y plano. En La rubia del camino, las dos mujeres están fuera de campo, por lo tanto, nunca se muestra la habitación y al bebé solo lo vemos cuando Betty aparece con él, justamente, envuelto en una manta.

Distintos autores han remarcado la ausencia de niños y de madres como uno de los rasgos principales de la comedia romántica de Hollywood. Por un lado, estas películas ponen en escena una nueva concepción de la pareja, minimizando la finalidad procreativa del modelo familiar tradicional donde la mujer debe responder al mandato de maternidad y priorizando un vínculo amoroso basado en el compañerismo y en la sexualidad mutua ${ }^{19}$. Por otro lado, la falta de niños también radica en que son los mismos integrantes de la pareja romántica los que se comportan como tales abandonando la solemnidad de la adultez y entregándose al juego que, en la screwball comedy, «está asociado con la espontaneidad, la improvisación y el intercambio de roles». ${ }^{20} \mathrm{Si}$ bien

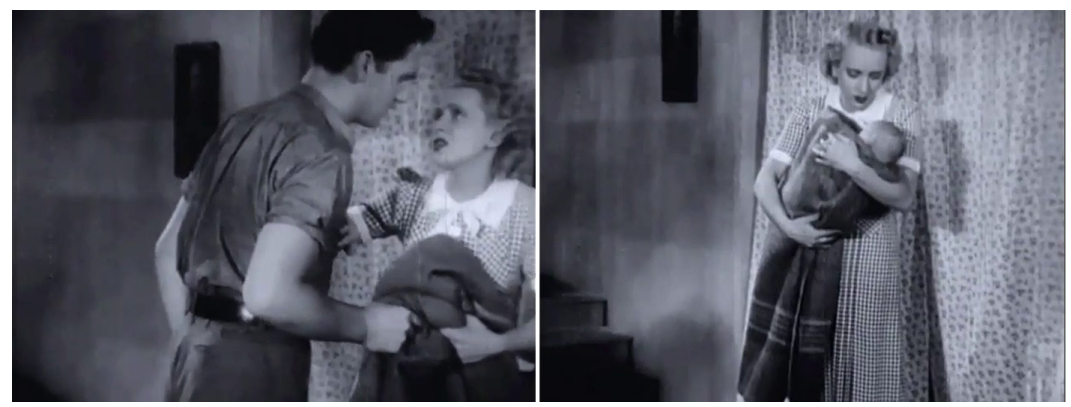

Izquierda: Betty detiene a Julián en el umbral. Derecha: La inesperada imagen maternal de Betty. La rubia del camino (Manuel Romero, 1938). 
Romero incorporó progresivamente muchos de estos elementos en obras posteriores, en su primera adaptación de la comedia romántica hollywoodense no solo emparenta feminidad y maternidad, sino que tampoco deja demasiado lugar para el juego en los términos que lo plantea la screwball comedy. Betty es la única niña y el rol de Julián es reeducarla, no jugar con ella. Se podría afirmar que tanto Peter como Julián poseen un discurso que apela a la infantilización despectiva de las mujeres (ambos usan el término mocosa/brat para referirse a sus respectivas compañeras de viaje) y consideran que una paliza aleccionadora es un medio válido para domarlas en la tradición de La fierecilla domada; pero en Sucedió una noche las lecciones son de ida y vuelta, forman parte de un intercambio lúdico y erótico. Por el contrario, Julián nunca permite ser ridiculizado, no tiene nada que aprender de ella y tampoco se advierten insinuaciones sexuales elocuentes de su parte, probablemente, como dice Karush, por «la identificación de Julián — y de la gente pobre en general— con la esencia de la rectitud moral». ${ }^{21}$ Esta representación de la clase trabajadora como un colectivo sin fisuras ante la aparición caótica de «la niña bien» (los personajes populares usan esta expresión - tanguera - para referirse a ella, mientras que sus familiares la llaman chica o joven moderna) tiene como consecuencia una férrea oposición entre el mundo de los ricos y el mundo de los pobres que no admite términos medios ni habilita la inversión de las identidades sociales y genéricas en el segundo grupo. La pregunta es si Betty será capaz de modificar sus orígenes para formar parte de esa comunidad popular y rural.

Según Northrop Frye, la comedia shakespeariana se estructura mediante un movimiento del «mundo ordinario al mundo verde, y viceversa», ${ }^{22}$ el cual habilita un nuevo orden social. Un número considerable de screwball comedies incorporó el «mundo verde» como un espacio idílico en el cual la pareja experimenta una transformación que sería imposible bajo la lógica de la sociedad ordinaria. En el caso de La rubia del camino, el retiro del mundo cotidiano está representado en el viaje por caminos rurales que realizan los dos personajes y que permite el enamoramiento interclasista. De manera consecuente con la tesis general de la película, Betty es quien atraviesa la transformación más profunda. Desde cambios simples, como abandonar el brillante vestido de fiesta por el modesto vestido que le presta la enamorada de Julián (celosa pero solidaria como todos los humildes de esta historia) y la adopción de las costumbres gastronómicas populares (come salamín y toma mate); hasta cambios profundos, como el despertar de su instinto maternal, y, definitivamente, como el reemplazo de su apodo de «rica» por el nombre original, más criollo, que le gusta a Julián: Isabel.

Cuando llegan a Buenos Aires, Betty les explicita a sus padres el efecto que tuvo esta experiencia: «No crean que soy la misma de antes. Este viaje me ha transformado. Vengo hecha una mujer». Sin embargo, la película no admite una reconfiguración de las relaciones sociales en la ciudad y la única opción para que triunfe el amor interclasista es volver al campo. Este espacio idealizado se encuentra delimitado por, y en oposición a, los otros dos grandes espacios de la película: Buenos Aires y Bariloche. En particular el hotel Llao-Llao, que había sido inaugurado recientemente producto del proceso de modernización territorial encarado por el Estado, y que buscaba explotar el turismo de elite configurando «las imágenes adecuadas a la anhelada 'Suiza argentina' $»^{23}$.

De allí que la compleja interacción entre género y clase que domina los términos del romance de Sucedió una noche, en La rubia del camino va de la mano con un tercer factor que opera de manera determinante sobre ese binomio: la cuestión de la identidad
[21] Matthew Karush, Cultura de clase, p. 219.

[22] Northrop Frye, «The Argument of Comedy», en Paul Lauter (ed.), Theories of Comedy (New York, Anchor, [1948] 1964), p. 456.

[23] Anahí Ballent y Adrián Gorelik, «País urbano o país rural: La modernización territorial y la crisis», en Alejandro Cataruzza (dir.), Crisis económica, avance del Estado e incertidumbre politica (1930-1943) (Buenos Aires, Sudamericana, 2001), p. 170. 
[24] Cecilia Tossounian, «The Argentine Modern Girl and National Identity, Buenos Aires, 1920-40», p. 233.

[25] Cecilia Gil Mariño, «Una industria de "lo nuestro". Gestos antiimperialistas en el proceso de nacionalización de los cines argentino y brasileño en los primeros años del sonoro» (Foros del Programa Interuniversitario de Historia Politica, $\mathrm{n}^{\circ}$ 6, 2017), p. 6.

[26] Singerman tuvo que abandonar el rodaje por un problema contractual, pero hubiese sido interesante ver a la actriz que siempre hizo de mujer indisciplinada enfrentándose a una actriz proveniente de Hollywood.

[27] Calki, «La modelo y la estrella, divertida, vivaz, es otro éxito de Manuel Romero» (El mundo, 16 de marzo de 1939), s/d. nacional. Frente a la modernidad elitista, ociosa, y extranjerizante de Buenos Aires, del Llao-Llao y, en consecuencia, de Betty y su clase; el campo argentino funciona como un resguardo de autenticidad, tradición popular, solidaridad y dignidad por el trabajo y, por lo tanto, es el sitio ideal para el renacimiento de Betty en Isabel. Al comienzo de la película, ante el torbellino de maltrato y caprichos con el que se presenta a Betty en la historia, el abuelo les decía a los padres: «es lo que todos hemos hecho de ella: una chica moderna». Y más tarde le aconsejaba a su nieta «una buena sacudida, un amor verdadero, un sufrimiento, un castigo», es decir, lo que efectivamente hace Julián con ella. Cecilia Tossounian ha observado que en la representación de la «chica moderna» en la cultura de masas de los años veinte y treinta «hay una clara crítica a una elite porteña europeizada y cosmopolita, a la cual se la responsabiliza de que Argentina haya perdido su 'alma auténtica'». En este sentido, la chica moderna es figurada como un «agente de desnacionalización y emasculación de la identidad argentina y sus críticas generalmente asumen la forma de un categórico regreso a un estilo de vida y a una feminidad tradicionales». ${ }^{24}$ Lo interesante de esta primera screwball comedy criolla es que Romero adoptó un género foráneo para usarlo como medio de expresión de una retórica explícitamente anti-extranjera o anti-extranjerizante que le permitió reencausar a un personaje moderno y transnacional como el de la chica moderna. En el cine de los años treinta, como ha señalado Cecilia Gil Mariño, «americanización y nacionalización fueron procesos colaborativos y su tensión 'aparente' — nacional/extranjero- fue un elemento muy importante [...] para desarrollar un producto diferenciado capaz de competir con los filmes de Hollywood». ${ }^{25}$ El proceso de americanización de la cultura de masas argentina convivió con una suerte de «gesto y/o sensibilidad antiimperialista» subyacente que no respondía a un proyecto ideológico específico sino a lógicas comerciales donde la «autenticidad nacional» era una narrativa funcional a este objetivo.

Si bien Romero apeló a esta estrategia en muchas ocasiones, hay un caso particularmente interesante que vale mencionar porque el conflicto nacional/extranjero se vuelve explícito ya no por la adopción de costumbres foráneas sino por la intrusión de una mujer extranjera. La modelo y la estrella, la segunda película que el director escribió para la misma pareja de actores — aunque Singerman luego fue reemplazada por Alita Román - cuenta un triángulo amoroso en el cual la tercera en discordia es una cantante estadounidense interpretada por June Marlowe. ${ }^{26}$ El personaje de Borel, que en la película anterior era un símbolo de masculinidad y argentinidad inalterable, aquí es una promesa musical argentina víctima de la estadounidense, una mujer «completamente moderna» y «excéntrica» según se la define. Por un lado, entonces, está la mujer moderna y extranjera para quien ni el matrimonio, ni la patria, tienen valor; por el otro, está el sacrificio de la mujer trabajadora y nacional que busca la felicidad de su hombre. La eventual victoria de la mujer argentina sobre la extranjera evoca una vez más la ambivalente relación de Romero con Hollywood. Calki, en la crítica del estreno, leyó acertadamente esta característica: «Manuel Romero, director múltiple, que acaba de hacer una película tango, hace ahora una comedia foxtrot. Teatro cinematográfico a la moda de Hollywood. Pero con espíritu criollo». El «toque criollo», según Calki, residía en la «leve tomadura de pelo a los norteamericanos» y en cierto revanchismo patriótico: «Ellos, en sus films, nos ven a los argentinos a su gusto. Justo es que, una vez, le devolvamos la pelota». ${ }^{27}$ Es decir, apropiarse inescrupulosamente de los géneros narrativos y los personajes de Hollywood, pero al mismo tiempo representar a la actriz hollywoodense como una ladrona del genio musical nacional. Gloria (Román) 


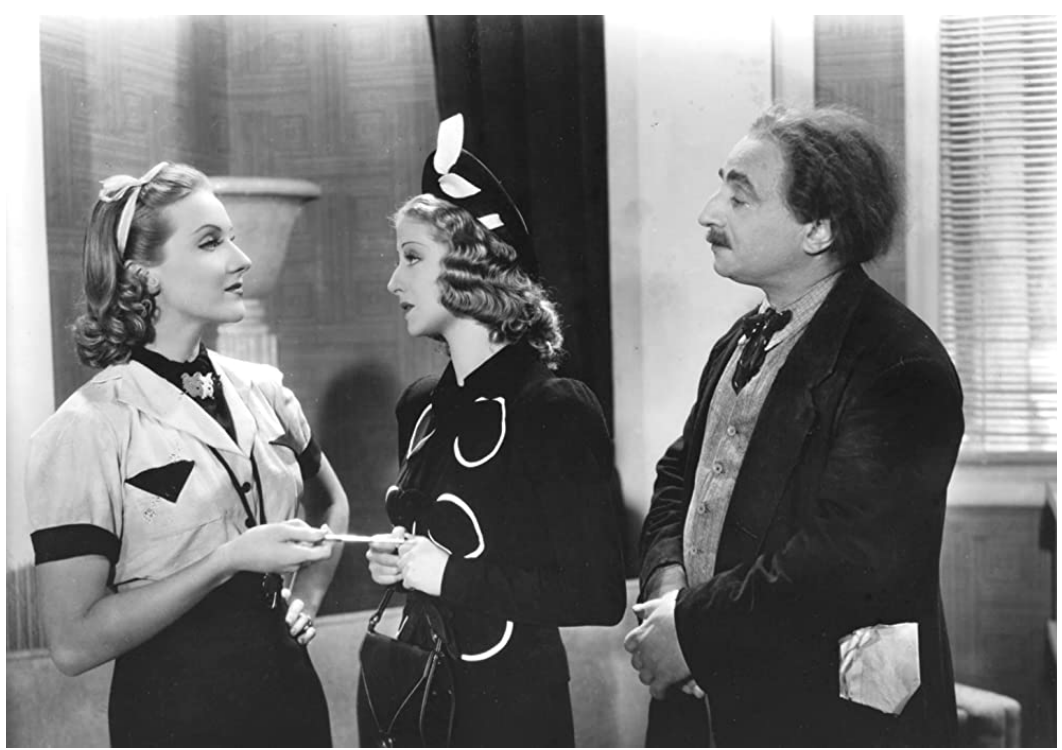

Alita Román, Marcelo Ruggero y June Marlow en La modelo y la estrella (Manuel Romero, 1939).

lo sintetiza en su reclamo a Barbara (Marlowe): «¿Por qué viene a aquí a robarme a Jorge? ¿No hay bastantes hombres en su país? ¿Le gustaría que yo fuera a Hollywood a robar a Robert Taylor?».

Ahora bien, el factor «anti-yanqui» de La modelo y la estrella es muy potente; por lo tanto, la estrella extranjera no tiene demasiado lugar en el mundo de Romero. Pero ¿la chica moderna extranjerizante (no extranjera) es realmente una amenaza? ¿Es tan fácilmente domesticable por el hombre de campo como parece sugerir La rubia del camino? Ya en esta película, aun cuando los binomios ciudad/campo, nacionalismo/ cosmopolitismo, ricos/pobres y tradición/modernidad están claramente definidos y no parecieran dejar lugar a una lectura por fuera de estas oposiciones maniqueas, es necesario preguntarse si el sentido que Romero le dio al romance interclasista implica la sumisión o desaparición total de la «modernidad» e independencia de Betty. Existen dos cuestiones que considero importante mencionar.

¿Por qué Julián no se queda con Lucía (Sabina Olmos), una mujer que cumple con todos sus ideales de feminidad y argentinidad, en la primera parada del camino? En esta secuencia, ambos dejan a Betty durmiendo en la habitación y salen al patio. Lucía comienza a cantar un tango titulado «Muchachita de campo» y Julián la acompaña con la guitarra. La letra habla de una mujer expectante por el amor de un hombre que nunca llega. Betty se levanta aturdida por el sonido, se acerca a la ventana y hace un gesto de fastidio. Todavía tiene puesto el lujoso y brillante vestido de fiesta, pero se lo saca y se pone un vestido sencillo que pertenece a Lucía. La canción termina y cuando Julián, emocionado por su voz, está a punto de besar a la muchachita de campo, aparece Betty para interrumpirlo: «Oiga chofer, he resuelto que sigamos viaje ahora mismo». Julián acata la orden y Lucía se lo recrimina, luego maldice en soledad a «la niña bien». Los distintos análisis sobre La rubia del camino han omitido esta escena (muy probablemente porque está recortada de las copias en circulación) ${ }^{28}$ y solo mencionan la segunda canción de la película, «La canción del camino», en la que Julián y Betty, ya aliados, celebran la argentinidad. Sin embargo, aquel primer tango — «Muchachita de campo»— que Betty no canta, sino que interrumpe, es la condición
[28] Sin embargo, no está perdida. Curiosamente el fragmento con «Muchachita de campo» puede encontrarse aislado en YouTube (https://www.youtube.com/wat$\mathrm{ch} ? \mathrm{v}=6 \mathrm{dqQR} 17 \mathrm{dYeM})$. 
de posibilidad para todo lo demás y es el único momento en que Julián se somete por completo a la chica moderna. Al igual que Ellie en Sucedió una noche, Betty reconoce su deseo antes que el hombre y «expande» ${ }^{29}$ la narración para conquistarlo. Si no fuera por ella, el incipiente romance (y la película en sí) hubiera terminado en la casa de Lucía. El motor de la narración es Betty. Ella aspira a romper con una tradición de pasividad femenina que aparece expresada en la letra del tango cantado por Lucía: «Por el largo camino tú lo viste marchar / y hoy sólo es tu destino: esperar y esperar».

Por supuesto, luego asistimos a los distintos modos de domesticación que he analizado anteriormente y que concluyen con Betty renunciando a su nombre de rica. Pero en el final de la película hay un pequeño gag, a primera vista insignificante, que podría ser leído como un guiño que sugiere cierta impostura en esta Betty/Isabel dócil y domesticada. Después de la separación de la pareja en Buenos Aires, la acción regresa al campo para cerrar la historia. Julián llega con su camión a la casa del amigo italiano y Betty, demostrando que ya no es la misma de antes, lo sorprende con el bebé de los amigos en sus brazos. Él se emociona e intenta besarla. Pero de pronto, la idílica imagen maternal y romántica se interrumpe porque ella lo pincha accidentalmente con un alfiler. Disciplinar a la unruly woman pareciera no ser tan fácil ni deseable. Ella deja al bebé y él la levanta sobre sus hombros para subirla al auto (en un gesto más amoroso y lúdico, opuesto al que había tenido a principio de la historia con un sentido paternal y punitivo). ¿Hasta qué punto, entonces, la chica moderna puede ser domada bajo la «ideología del maternalismo» ${ }^{30}$ ? En las próximas películas de Romero la chica moderna renació una y otra vez pese a los intentos de domesticación, y en cada ocasión se caracterizó por su indomabilidad. En los siguientes dos apartados analizaré distintas formas de indisciplina en las mujeres romerianas. Primero en la esfera pública (el mundo del trabajo) y luego en la esfera privada (el matrimonio) donde un personaje de Paulina Singerman vuelve a lidiar con el mandato de maternidad pero desde una perspectiva bastante singular.

\section{Chicas modernas y mujeres trabajadoras}

[29] Rowe dice que la virgen de la comedia romántica «expande la narración» y aplaza la clausura. Véase Kathleen Rowe, The Unruly Woman, p. 134.

[30] Tomo el concepto de «ideología del maternalismo» de Marcela Nari, quien ha estudiado el conjunto de prácticas y políticas que fomentaron el ideal de «naturaleza maternal» de las mujeres durante la primera mitad del siglo XX en Buenos Aires. La autora enfatiza especialmente el caso de la década del treinta, donde el índice de natalidad cayó drásticamente y donde «los rasgos de 'modernidad' parecían desvirtuar, con tanta o más fuerza que antes, la familia y la maternidad». Véase Marcela Nari, Politicas de maternidad y maternalismo politico. Buenos Aires, 1890-1940 (Buenos Aires, Biblos, 2004), p. 21.
Tres meses después de la aparición de La rubia del camino, Romero estrenó Mujeres que trabajan. La protagonista es nuevamente una joven de clase alta que se sumerge en el mundo popular, pero la perspectiva con la que la película encara la relación entre género y clase es totalmente diferente a la de su antecesora. La mujer rica no tiene que dar cuenta del instinto maternal ante un hombre, sino que debe demostrarles a sus pares de género (trabajadoras de tienda) que puede ser solidaria, que puede pertenecer a su comunidad y abandonar el egoísmo que caracteriza a la clase social de la que proviene. Si bien es cierto que el populismo romeriano se mantiene y los pobres siguen siendo el grupo social predilecto y lleno de bondades, con esta película - y luego de manera definitiva con Elvira Fernández, vendedora de tienda - no es solo la chica moderna la que se beneficia del contacto con el pueblo, sino también a la inversa. Ella, gracias a su inestabilidad de clase, es capaz de destrabar problemas específicos del género femenino. No es casual que ambas historias estén ambientadas en el espacio laboral de la tienda, donde el enfrentamiento social convive con el acoso o el abuso masculino.

Si La rubia del camino narra la historia de una única mujer (quien además es hostil con la «muchachita de campo» que amenaza con quitarle su hombre), en Mujeres que trabajan la pluralidad de mujeres y la comunión femenina (ya sugeridas desde el título) parecieran ser elementos más importantes que la trama romántica de celos y 
amores perdidos. De hecho, en gran parte de la película Ana María (Mecha Ortiz) renuncia al amor y una vez que se transforma en trabajadora le dice al (ex)novio de clase alta: "Ahora yo soy una obrera, una unidad más en la masa anónima de las mujeres que trabajan». En todo caso, la restauración del amor y el final feliz serán resultado del compañerismo. Lo mismo podría afirmarse de Elvira Fernandez, que lleva en el título el nuevo -y ordinario - apellido elegido por Elvira Durand (Paulina Singerman). Ella le pide a su prometido suspender la relación para convertirse en «Elvira Fernández, una empleadita humilde perdida entre miles de muchachas que se ganan el pan». Romero funde a las chicas modernas con la masa no solo a partir del discurso y de la narración, sino también visualmente, ya que ambas películas culminan con figuras de la multitud. Esto le permite plantear, tímidamente en Mujeres que trabajan y explícitamente en Elvira Fernández, una serie de problemáticas relacionadas con el mundo del trabajo inéditas para el cine argentino. Y para ello el cine de Hollywood vuelve a cumplir una función mediadora.

Cuando se estrenó Mujeres que trabajan los diarios identificaron, otra vez, la influencia «de esas comedias de conjunto a la manera yanqui». ${ }^{31}$ La Nación fue más específico — «El frecuentador de los espectáculos cine-

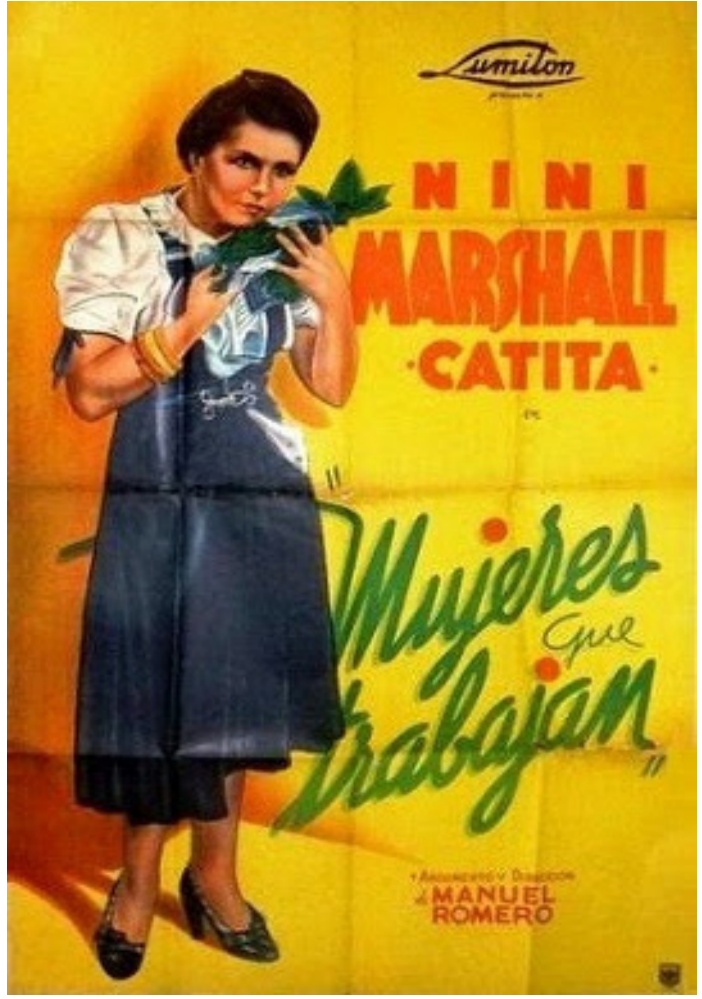

Afiche de Mujeres que trabajan (1938). matográficos ha de reconocer [...] la atmósfera, la entraña y hasta detalles de películas extranjeras $\rangle^{32}$ - y señaló la similitud con Damas de teatro (Stage Door, Gregory La Cava, 1937). Allí Katherine Hepburn interpretaba a una joven de buena posición económica que, decidida a cambiar de vida para dedicarse al teatro, abandona sus privilegios y se hospeda en una pensión de actrices y bailarinas. Pero Romero cambia la profesión de sus personajes y las hace trabajadoras, vendedoras de las grandes tiendas Stanley, reforzando todavía más las tensiones de clase que existían en la película norteamericana y llevando el drama teatral original hacia un melodrama más plebeyo y maniqueo hibridado con la comedia.

La película comienza con una suerte de prólogo en el que se plantea una visión descarnada de las diferencias morales entre ricos y pobres. Por un lado, los jóvenes privilegiados y decadentes que salen borrachos de una boîte por la madrugada. Por el otro, las mujeres que trabajan preparándose para asistir a sus puestos laborales. Los dos grupos se encuentran en un bar y Ana María del Solar, borracha, se burla del orgullo de las mujeres trabajadoras. Luisa (Pepita Serrador), la comunista del grupo, le advierte que se detenga porque «nadie está libre de una broma del destino». Tiene razón: «El banquero del Solar fue hallado muerto en la madrugada», se lee en un titular del diario matutino. Ana María queda huérfana y pobre. Su chofer, Lorenzo (Tito Lusiardo), se apiada de ella y la lleva a vivir a la pensión de vendedoras.

Como ha observado Pascual Quinziano, la comedia argentina raramente se manifiesta de forma «pura» debido a los aditamentos provenientes «tanto del melodrama como del costumbrismo social». ${ }^{33} \mathrm{Y}$ Mujeres que trabajan es especialmente oscilante en cuanto a su género. Ana María, aun siendo pobre, posee ciertos privi-

[31] «Mujeres que trabajan es una divertida y ágil comedia sentimental» (La Prensa, 7 de julio de 1938), p.18.

[32] «Una feliz combinación es Mujeres que trabajan» (La Nación, 7 de julio de 1938), p. 14.

[33] Pascual Quinziano, «La comedia. Un género impuro», en Sergio Wolf (comp.), Cine Argentino. La otra historia (Buenos Aires, Ediciones Letra Buena, 1992), p. 132. 


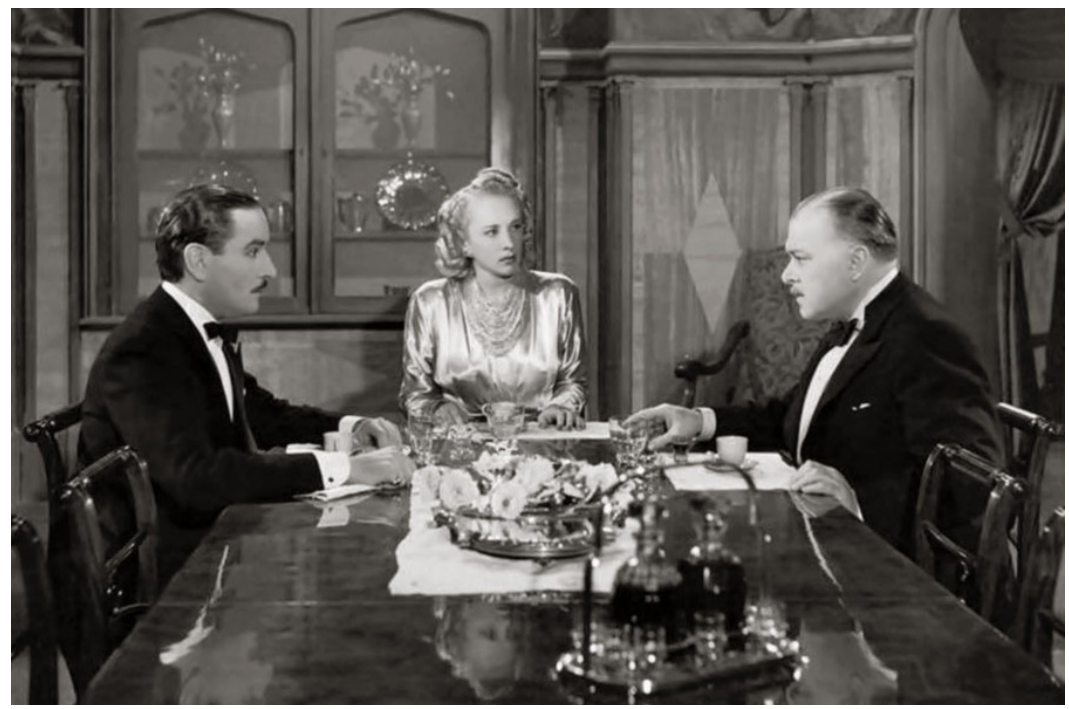

Fotograma de Elvira Fernández (1942).

legios con el gerente de la empresa, quien la corteja mientras mantiene una relación clandestina con la humilde Clara (Alicia Barrié). Sin embargo, la película avanza hacia un final más o menos feliz y conciliador debido a la hibridación con la comedia. Si la vivacidad característica de toda chica moderna en este caso se encuentra apaciguada por la fatalidad, Romero balancea esto mediante el personaje de Niní Marshall, y ninguna película que incluya a Catita puede ser definida como un drama o un melodrama puros. Cuando Lorenzo narra a las chicas la historia de la joven millonaria que quedó huérfana y sin dinero, una dice: « ¡Uy, parece una novela!». Pero Catita la interrumpe e introduce otro intertexto hollywoodense, una screwball comedy:

CATITA: Es como una película que vimos anoche en el cine a la vuelta de casa. Resulta de que ella es pobre, ¿no? Y el padre del muchacho tiene una gran fábrica de banco // CHICA 1: ¿Cómo, cómo? Yo vi esa cinta, el padre es un gran banquero // CATITA: Bueno, ¿no es lo mismo? // CHICA 2: No, mi hija. Un banquero es un financista // CATITA: ¿¿Lo qué?! // CHICA 1: Un negociante, un bolsista... // CATITA: Bueno, yo no sé si tenía fábrica de banco o de bolsa, ¿no? Pero resulta de que...

Lorenzo rápidamente cambia de tema, pero Catita no estaba errada en su comparación entre la historia de Ana María y lo que vio en el cine. El argumento que intenta explicar es el de Una chica afortunada (Easy Living, Mitchell Leisen, 1937), una screwball comedy escrita por Preston Sturges que cuenta el romance entre una chica trabajadora que vive como rica por error y el hijo de un banquero que harto de la «vida fácil» deviene trabajador. A Catita la historia de Ana María no le recuerda a un melodrama sino a una comedia romántica que no le dejan terminar de contar. Si se lo hubiesen permitido, hubiera dicho que el banquero de Una chica afortunada entra en quiebra como le sucedió al padre de Ana María pero que finalmente en el horizonte hay un final feliz, tal como sucederá en Mujeres que trabajan.

Cuando la comunista se entera de que Ana María es la misma persona con la que se enfrentó en la lechería y que su presagio se había cumplido, ensaya un discurso 
muy duro contra ella mientras presenta a las chicas de la pensión como parte de una multitud de trabajadoras. Cada una carga con una historia de esfuerzos al igual que «las cien muchachas de la tienda. Y los millones de muchachas que trabajan en el país». $\mathrm{Y}$, dice, «todas son dignas del respeto y la admiración de los inútiles como usted y los suyos».

Romero suele caricaturizar a personajes de este tipo y presenta a «las ideas socialistas» como desviaciones en el camino de la mujer hacia el matrimonio. De hecho, la película termina con un plano de Luisa lagrimeando en el que dice: «Tal vez si yo hubiera encontrado un amor no leería tanto». Sin embargo, en esta historia donde los principios colectivos son clave para los personajes, sus ideas marxistas (efectivamente se la ve leyendo a Karl Marx) se concretizan en un relato que prioriza el bien común. Esto puede verse en tres situaciones clave.

En primer lugar, Luisa propone criar colectivamente al hijo de Clara que Stanley (Enrique Serrano) se niega a reconocer y así desactiva la narrativa moralizante de «la muchachita que dio el mal paso», la cual condena a las mujeres pobres y del campo seducidas por la sexualidad de la ciudad y el lujo de una clase a la que no pertenecen. ${ }^{34} \mathrm{El}$ accionar de Clara no adquiere la forma del pecado ni es obligada a hacerse cargo del hijo no deseado. Pese al sufrimiento inicial, decide finalmente desentenderse de la crianza e irse de la pensión, y las pensionistas la apoyan en su decisión. Ningún melodrama punitivo aceptaría que una madre no mostrara devoción y sacrificio. En Mujeres que trabajan, en cambio, se produce cierta reconfiguración de los vínculos sociales que solo es posible en un género como la comedia, y que aquí toma la forma de una comunidad femenina alternativa en clara oposición al desamparo en el que suele quedar la heroína del melodrama. En segundo lugar, Luisa le reconoce a Ana María que decidiera cortar su vínculo con Stanley en defensa de Clara. Ana María, quien alguna vez fue una niña rica e individualista, ahora es, definitivamente, una mujer que trabaja. Y, en tercer lugar, como consecuencia de esta transformación de la joven de clase alta, hay que mencionar la concreción del sueño de Luisa de ver a la multitud de mujeres organizadas. Solo que el carácter explícitamente político de la organización gremial con el que pudo haber sonado la joven comunista sufre un desplazamiento de sentido: Luisa arma un plan colectivo para que Ana María recupere a su primer novio, a punto de casarse con otra mujer. En un montaje acelerado de planos de conjunto, vemos a cientos de vendedoras corriendo como un torbellino y tirando todo lo que se cruza a su paso. Las mujeres salen en masa de la tienda Stanley, entran a la iglesia donde se encuentra Carlos, lo agarran a la fuerza y se lo dehvuelven a su novia original.
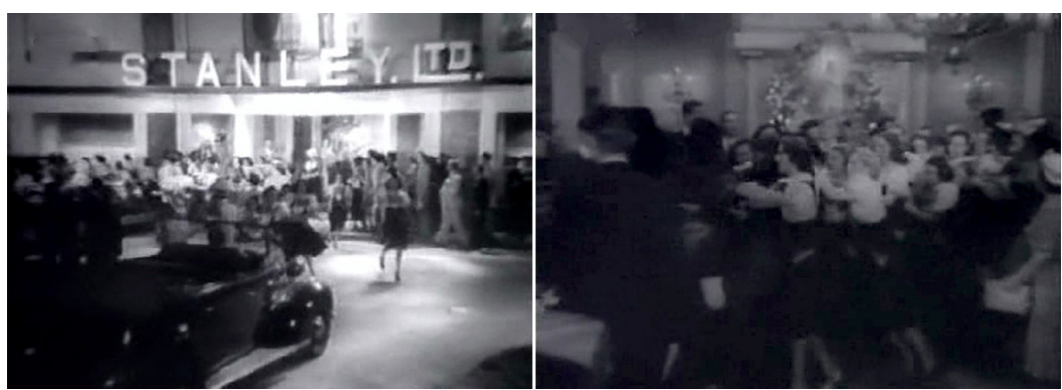

Izquierda: La horda de trabajadoras saliendo de la empresa. Derecha: La multitud irrumpe en la iglesia. Mujeres que trabajan (Manuel Romero, 1938).
[34] El «mal paso» era un tópico recurrente en letras de tango, folletines e historias cinematográficas de matriz melodramática. Véase Diego Armus, «El viaje al Centro. Tísicas, costureritas y milonguitas en Buenos Aires, 1910-1940» (Boletín del Instituto de Historia Argentina y Americana Dr. Emilio Ravignani, vol. 3, $\mathrm{n}^{\circ} 22,2000$ ). 
[35] Calki, «Muy buena realización tiene el film Mujeres que trabajan» (El Mundo, 7 de julio de 1938), p. 27.

[36] Mirta Zaida Lobato, Historia de las trabajadoras en la Argentina (1869-1960) (Buenos Aires, Edhasa, 2007).

[37] Graciela Queirolo, "Vendedoras: género y trabajo en el sector comercial (Buenos Aires, 1910-1950)» (Estudos Feministas, vol. $\left.22, n^{\circ} 1,2014\right)$, pp. 29-50.

[38] Los folletines sentimentales que tenían a vendedoras como protagonistas no las mostraban manifestándose por sus derechos como efectivamente hacían. Véase Graciela Queirolo, «Vendedoras: género y trabajo en el sector comercial (Buenos Aires, 19101950)», p. 44.

[39] Graciela Queirolo, «Vendedoras: género y trabajo en el sector comercial (Buenos Aires, 1910-1950)», p. 39

[40] Graciela Montaldo, Museo del consumo. Archivos de la cultura de masas en Argentina (Buenos Aires, Fondo de Cultura Económica, 2016), p. 33.
Esta última secuencia impactó a Calki quien, a diferencia de otros cronistas, mostró menos interés por la cuestión argumental que por los «movimientos de masas» de la película: «Lo que tiene el cine de arte de masas lo ha captado ampliamente Romero. Hay allí escenas de conjunto, como la que precipita el final, que merecen amplios elogios» ${ }^{35}$ De cierta manera, Calki observaba que el cine de Romero, como arte de masas, estaba haciéndose cargo de reproducir a su sujeto predilecto. La representación de multitudes para 1938 todavía era escasa en el cine argentino y menos aún si se buscan multitudes conformadas por mujeres. En este sentido, Romero, moderno y sensible a los cambios sociales, identificó un sujeto emergente que no tenía representación en la pantalla: las mujeres que trabajan y en particular las vendedoras de tiendas departamentales. Si bien durante el período de entreguerras el trabajo femenino asalariado «se amplió de tal modo que abarcó una extensa variedad de actividades», ${ }^{36}$ dentro del sector terciario el nuevo rubro de las vendedoras de tiendas fue especialmente absorbido por la cultura de masas. Caracterizadas por su belleza y buena presencia, estas jóvenes ilustraban revistas, tiras cómicas y publicidades, y protagonizaban folletines sentimentales que narraban los deseos y los peligros de la movilidad social. ${ }^{37}$ Pero lo destacable del caso de Romero es que se aleja de la representación convencional de la vendedora como la que se podía encontrar en La vendedora de Harrods (1919) de Josué Quesada. No deja de mostrar a jóvenes trabajadoras que fantasean con la vida y los objetos de sus clientas, o que sueñan con casarse con Robert Taylor como Sarita (Alita Román), sin embargo, también pone en imagen otros comportamientos invisibilizados. ${ }^{38}$

$\mathrm{Si}$, como plantea Queirolo, ${ }^{39}$ a las vendedoras se les exigía buen humor, simpatía, recato, discreción y amabilidad con el público consumidor; no deja de ser atípica la operación de Romero en la que invierte estos valores contando la historia de un grupo de vendedoras que se enfrentan con su patrón y cuya resolución - aunque sea con el disfraz de un objetivo sentimental (reunir a Ana María y Carlos) — consiste en cientos de mujeres abandonando sus puestos de trabajo, rompiendo la mercadería y golpeando a sus clientes. La comedia sentimental, muchas veces considerada un género menor, pasatista y conciliador, es capaz de proponer una serie de imágenes disruptivas difíciles de encontrar en otros géneros (el melodrama, que es el modo narrativo femenino y feminizado por excelencia, abandona a la mujer en su soledad; y aquellos géneros que muestran grandes movimientos de masas ponen en pantalla a hombres, no a mujeres, en acciones épicas de conjunto). En este sentido, el final de Mujeres que trabajan presenta el caos de una turba femenina que expresa lo que Graciela Montaldo definió como «un miedo central del siglo XX: la amenaza que tanto las mujeres como las masas representan para la burguesía occidental y sus valores». ${ }^{40}$ Claro que la secuencia de imágenes también avanza hacia el apaciguamiento de esa furia culminando en el matrimonio y en la vuelta al trabajo, pero la trasgresión ya fue registrada gracias al marco subversivo que habilita la comedia.

En 1942 Romero volvió a abordar el conflicto laboral de un grupo de vendedoras $\mathrm{y}$, si bien en esta ocasión no recurrió a ninguna distracción sentimental, tampoco abandonó la estructura de la comedia romántica. De hecho, Elvira Fernández, vendedora de tienda es su screwball comedy más pura. Lo peculiar es que no eligió una comedia romántica hollywoodense cualquiera sobre la cual construir su historia, sino una que se caracterizó por llevar a la pantalla de manera excepcional el conflicto laboral: $E l$ diablo burlado (The Devil and Miss Jones, 1941). Michael Rogin se ha preguntado por qué durante la época del New Deal y de la CIO (Congress of Industrial Organizations), 
momento en el cual la actividad sindical tuvo una presencia activa y definitoria, casi no hubo películas que trataran explícitamente formas de organización sindical urbana. Después de revisar minuciosamente el acotado conjunto de casos que tocan el tema, en el que se destacan diversos ejemplos con representaciones negativas de gremialistas (agitadores y mafiosos) y las dos películas emblema de John Ford - Las uvas de la ira (The Grapes of Wrath, 1940) y iQué verde era mi valle! (How Green Was My Valley, 1941) - que, a pesar de mostrar de manera heroica la militancia gremial, no representan a la clase trabajadora moderna y añoran una comunidad agraria ya perdida; Rogin concluye que solo El diablo burlado, una comedia romántica, pone la cuestión de la organización política de los trabajadores en el centro y tiene una visión positiva sobre ella:

Solo esta película muestra desobediencia 'no tan civil' en el piso de una tienda; solo en esta película el sindicato triunfa. Solo esta película forja un sindicato a partir de la cultura de masas urbana [...] The Devil and Miss Jones espera felizmente un «new deal». Esta olvidada película es una screwball comedy, en la cual un capitalista que se hace pasar por uno de sus empleados de la tienda departamental con el fin de disolver el sindicato, termina llevándolo a la victoria. ${ }^{41}$

Ni siquiera la famosa trilogía de Capra — a quien Romero admiraba - entra en esta categoría ya que su héroe, el hombre medio norteamericano, no se vinculaba con fuerzas colectivas organizadas sino con masas indiferenciadas e informes. La película de Sam Wood, entonces, le ofreció a Romero un medio ideal para narrar la organización sindical de las vendedoras en Elvira Fernández (ya insinuada tempranamente en Mujeres que trabajan). Después de estudiar tres años en Estados Unidos, Elvira Durand (Paulina Singerman) llega a Buenos Aires cuando su padre - dueño de los Grandes Establecimientos Durand - se encuentra en medio de un conflicto laboral. Asesorado por los cuatro gerentes que manejan su empresa, aprobó una reducción de personal provocando la reacción de los trabajadores y las trabajadoras que durante la cena de bienvenida de Elvira se presentan en la casa para exigirle explicaciones. Ella escucha la discusión y decide infiltrarse en las grandes tiendas departamentales para hacer justicia por ellos y, a la vez, reconciliarlos con su padre.

La extranjerización de Elvira, a diferencia de las chicas modernas de películas anteriores, no es una amenaza para la clase trabajadora sino para su propia clase. En su estadía en Estados Unidos, Elvira aprendió los principios del New Deal, los mismos que aprendió Romero viendo El diablo burlado: cuando su padre se niega a recibir a los delegados ella le dice: «Esa es otra cosa que aprendí en Norteamérica, Mr. Ford no tiene horas para sus empleados». Así como también aprendió los nuevos modelos de feminidad, y por eso se indigna cuando sus familiares la tratan como la niña caprichosa que alguna vez fue: «En aquel país la mujer es un ser adulto como el hombre». El novio acota: «Tiene razón Elvira, en estas tierras la mujer es considerada un ser débil, necesitada de protección». La tía se fastidia porque Elvira ahora es «seria» y «reflexiva». Efectivamente, esta mujer moderna incluso cambió su concepción del amor, al igual que Luis (Enrique Roldán), su prometido. Ambos concuerdan en que un matrimonio por compromiso no vale la pena y los dos quieren «estudiar a fondo [sus] sentimientos». En este sentido, cuando él le dice «has vuelto completamente yanqui» no hay que leerlo como una injuria sino como la posibilidad de una relación más sincera enmarcada en otro concepto del matrimonio como han planteado numerosas screwball comedies.
[41] Michael Rogin, «How the Working Class Saved Capitalism: The New Labor History and The Devil and Miss Jones» (The Journal of American History, 89:1, 2002), p. 98. 
[42] Elvira Fernández, vendedora de tienda tiene eficacia cómica» (El Mundo, 7 de julio de 1942), $\mathrm{s} / \mathrm{d}$.

[43] Michael Rogin, «How the Working Class Saved Capitalism», p. 108. Sobre la relación con la moda de las mujeres trabajadoras modernas argentinas, véase Cecilia Tossounian, $L a$ Joven Moderna in Interwar Argentina, p. 61.

[44] Ibid.

[45] Graciela Queirolo, «Vendedoras: género y trabajo en el sector comercial (Buenos Aires, 1910-1950)».
Este estilo más calmo que presenta el nuevo personaje de Singerman no dura demasiado una vez que ingresa de incógnito a la empresa del padre y así lo advirtió la prensa: «se transforma después, adquiriendo su típica e inimitable modalidad, cuando toma el disfraz de empleada de tienda y 'líder' de un movimiento revolucionario llevado hasta la caricatura». ${ }^{42}$ Pero «el movimiento revolucionario» está lejos de ser una caricatura; por el contrario, la unión de la caótica e indisciplinada Elvira (ahora apellidada Fernández) al resto de los trabajadores permite exhibir todo el proceso de una lucha gremial como no lo hizo ninguna otra película argentina. Al igual que $E l$ diablo burlado, en la versión nacional pueden encontrarse espías, buchones, carneros, trabajadores despedidos, listas negras, maltrato laboral, desobediencia civil, estrategias de boicot, asambleas, adhesiones de otros sindicatos, la huelga en sí, la marcha a la casa del patrón, la repercusión en la prensa y el proceso de construcción del líder y el mito.

Así como El diablo burlado muestra un proletariado femenino y «celebra a las muchachas gremialistas que venden, usan y disfrutan los consumos de moda», ${ }^{43}$ en el cine de Romero la circulación de objetos de consumo siempre fue muy importante y ayudó a definir los anhelos y contradicciones de sus protagonistas. Pero en este caso el director se sirve de la lucha política feminizada para mostrarle a sus espectadoras que podían desear las pieles que tenían las mujeres de clase alta (un motivo que ya se encuentra en Mujeres que trabajan e Isabelita) y a la vez reclamar por sus derechos; o, de acuerdo con el final de la película, que la lucha era un medio para democratizar el acceso a los bienes privativos. Según Rogin, en la película de Wood «la caída del patriarcado les permite a estas mujeres tomar el mando». ${ }^{44}$ En la película de Romero, entonces, se podría pensar que Elvira viene a cumplir un rol que ni siquiera Luis, el entusiasta vendedor y militante, puede alcanzar. Si bien, al principio de la historia, una de las chicas se enoja con el buchón de la tienda y manifiesta cierta bronca e impotencia — «Ah, si yo fuera hombre!»-, lo cierto es que no es un hombre quien se cobra venganza por las injusticias, tal como queda demostrado después de que Luis, el galán coprotagonista (Juan Carlos Thorry), intentara iniciar las primeras acciones de reclamo sin conseguir demasiada adhesión entre los compañeros y las compañeras.

El enemigo más directo que tienen las empleadas es Batistella (Julio Renato), el gerente que las acosa y exige favores sexuales a cambio de privilegios laborales. Elvira, con toda la indocilidad de la chica moderna pero también con la libertad de ser millonaria y no tener nada que perder, le da un cachetazo cuando intenta propasarse con ella. Con esta acción se gana su despido y también la admiración de todas las compañeras. Como ha señalado Queirolo, las vendedoras eran sometidas constantemente a acosos sexuales, obscenidades verbales y todo tipo de hostigamientos; ${ }^{45}$ pero al transponer estos problemas a la pantallas, Romero, al igual que en Mujeres que trabajan, no culpabiliza a la mujer bajo la imagen del «mal paso» ni la reivindica mediante algún acto heroico masculino (Luis casi no tiene acciones importantes, simplemente esta alucinado con Elvira, incluso le escribe una canción), sino que la premia con el reconocimiento de sus pares de género y sus nuevos pares de clase. La importancia de esta cachetada es tal que de aquí en adelante el conflicto entre patrones y trabajadores se radicaliza cada vez más y Elvira se convierte en un mito de lucha entre toda la clase obrera, incluidos otros sindicatos que se suman a la huelga general gracias a ella. Ya no son «las cien empleadas de la tienda» a las que aludía la comunista en su discurso de Mujeres que trabajan, sino las «millones de muchachas que trabajan en el país». 
Elvira Fernández se estrenó en el cine Broadway con una función a beneficio de la Federación de Asociaciones Católicas de Empleadas, compuesta en su mayoría por empleadas de las grandes tiendas comerciales, y caracterizada por «promover la convivencia armónica de las clases sociales rechazando la pretensión utópica de la lucha de clases $»^{46}$. Si bien la película termina con una armoniosa reconstitución de las relaciones entre capital y trabajo (los gerentes son expulsados; Elvira se casa con Luis y lo propone como el nuevo encargado del negocio; Durand es resignificado como el empresario honesto que se hizo desde abajo en lugar del frío financista con múltiples negocios diversificados), considerando las diversas formas de politización explícita a las que asistimos en

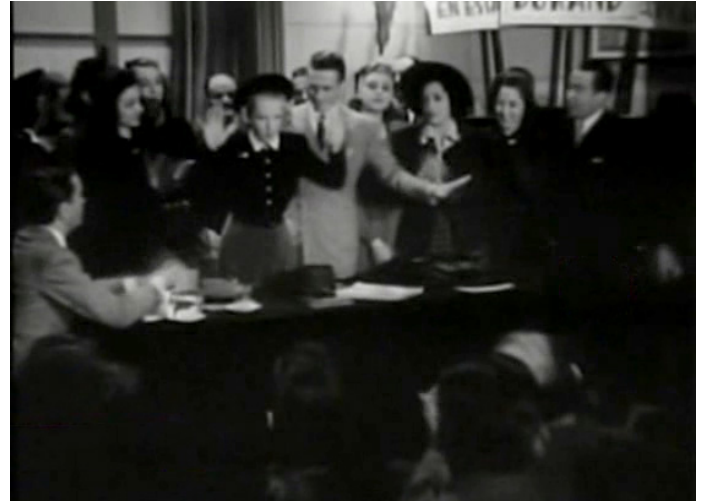

Elvira en el centro de la imagen se lleva toda la atención mientras estimula a sus compañeros. Elvira Fernández, vendedora de tienda (Manuel Romero, 1942). esta comedia romántica es difícil adivinar si la función a beneficio de la FACE se debió a una lavada de cara de la productora y de Romero (quien siempre tuvo problemas con los sectores moralistas) para evitar problemas futuros, a un real interés de ambas partes, o a que simplemente fue leída como una comedia inocente que hablaba sobre un grupo de alocadas empleadas de comercio. En cualquier caso, queda la pregunta abierta sobre si las vendedoras que vieron la película se sintieron más interpeladas por el final de cuento de hadas en el que los dos sectores liman mágicamente sus asperezas, o por el momento inmediatamente anterior en el que Elvira expone al acosador ante su padre y logra que sea despedido. Seguramente ambas narrativas fueran muy potentes - la reconciliación de clases y la reivindicación del género- pero teniendo en cuenta la probable identificación de las espectadoras con la empleada abusada y la progresión dramática que construye esa victoria, no sería extraño imaginar cierta preminencia de la segunda opción.

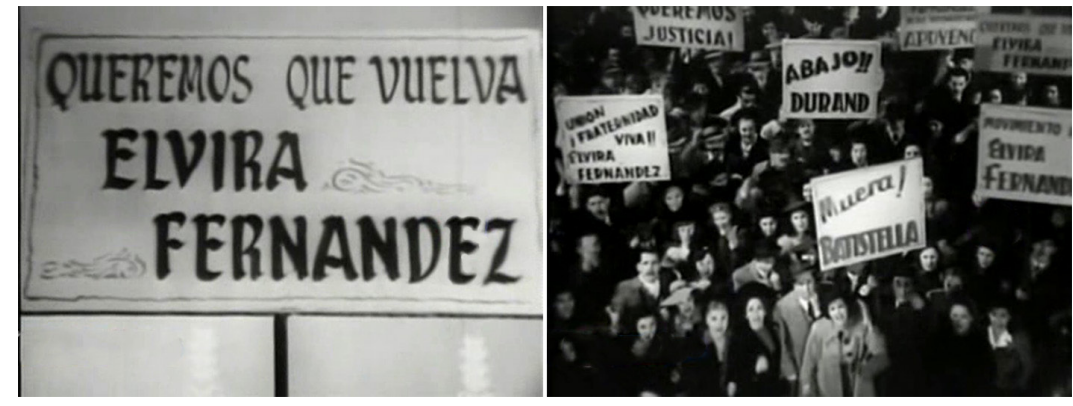

La protesta frente a la casa del patrón. Elvira Fernández, vendedora de tienda (Manuel Romero, 1942).

\section{Matrimonio}

Las mujeres de Romero pueden escapar de su hogar desafiando a sus padres, pueden enamorarse de hombres de otra clase social e incluso pueden organizarse colectivamente para enfrentar la explotación laboral; sin embargo, en su horizonte de rebeldía hay un límite bien definido que no puede ser transgredido: el matrimonio como consumación del amor. Lógicamente, estas películas son comedias románticas y, como tales, aspiran a la unión o reunión de la pareja después de superar una serie de obstáculos.
[46] Mirta Zaida Lobato, Historia de las trabajadoras en la Argentina (1869-1960), p. 188. 


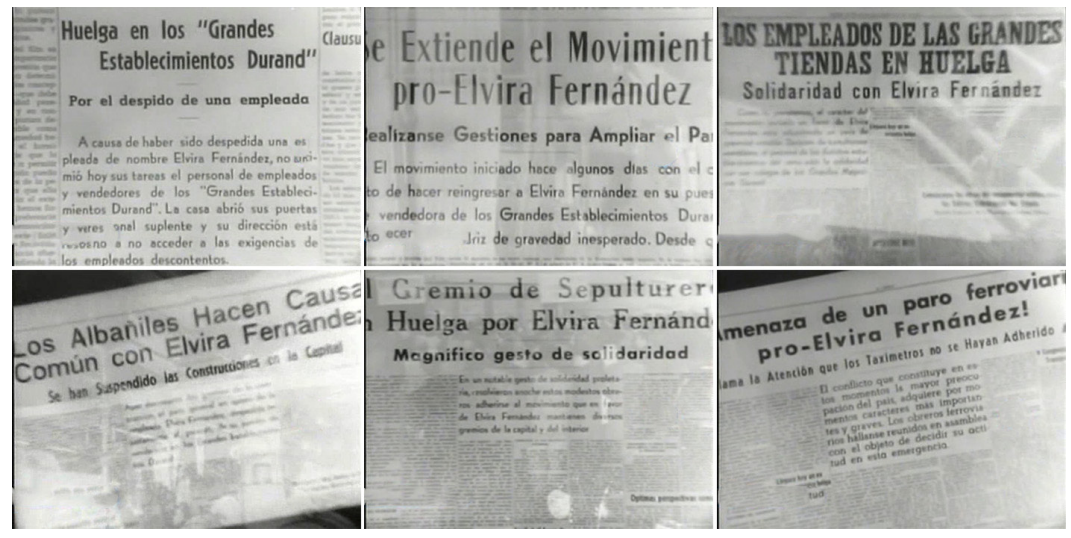

El apoyo de los otros gremios a la causa de Elvira Fernández. Elvira Fernández, vendedora de tienda (Manuel Romero, 1942).

¿Pero qué sucede cuándo se socavan de raíz estos principios vinculados con el cortejo, el amor y el matrimonio? Muchachas que estudian (1939) comienza en un Club Estudiantil Femenino. En el pizarrón se lee el título del debate del día: «El matrimonio y la mujer que estudia». El plano se abre y muestra a una mujer finalizando su exposición:

Una vida dedicada al estudio no necesita amor. El matrimonio hace de una mujer una esclava y la convierte en un ser inferior al hombre, su dominador secular. Hermanas estudiantes, seguid el ejemplo mío y el de mis amigas aquí presentes. Estableced una comunidad femenina y tratad de ser simplemente camarada de los hombres [...] El amor anula el genio de la mujer. El matrimonio destruye su potencia intelectual. La llamada sensibilidad femenina, que no vacilo en calificar de vulgar sensiblería, ha sido causa del fracaso de infinitos genios de nuestro sexo $[\ldots]$

La disertadora, Ana del Valle (Pepita Serrador), es una científica que dedica su vida a escribir un «tratado sobre la subdivisión de los cromosomas en los protozoarios». Está vestida de manera formal, con lentes y el pelo prolijamente atado. Asexuada y antiromántica, remite al personaje de la comunista que interpretó la misma actriz en Mujeres que trabajan. Allí leía a Carlos Marx y se burlaba del idealismo de sus compañeras enamoradas de hombres imposibles (una de su jefe, la otra de Robert Taylor). Las dos tienen una influencia sobre la joven moderna, pero si las ideas políticas radicales de Luisa convirtieron a su compañera desclasada en una mejor versión de sí misma, las ideas de Ana en Muchachas que estudian tendrán un efecto absolutamente negativo. Cuando termina la exposición se arma un gran revuelo entre las oyentes e Isabel (Alicia Barrié), una estudiante de medicina de buena posición económica, decide abandonar a su prometido e irse a vivir a la pensión estudiantil: «Cómo las envidio, vivir juntas entre amigas, lo de una para todas, lo de todas para una, esa es la única manera digna de vivir». Sin embargo, este proyecto de comunidad femenina no prospera como en Mujeres que trabajan o Elvira Fernández. Ana es la caricatura de una feminista, una figura mucho más controvertida que la de la chica moderna. A pesar de las representaciones ambiguas que se hacían de esta última en la prensa y en otros medios masivos (peligrosa y frívola pero a la vez bella y divertida), al fin y al cabo su rebeldía de juventud podía ser domesticada. Es decir, la chica moderna eventualmente crecía y se convertía en esposa o madre. El estereotipo de la feminista, en cambio, era 
usado «para advertir a las lectoras sobre los peligros de conquistar espacios que no le pertenecían y así transformarse en seres masculinos». ${ }^{47}$

Las ideas libertarias y cientificistas contra el matrimonio y el amor romántico van más lejos de lo que puede tolerar la comedia romántica. Si muchas de las películas de Romero proyectan una nueva y utópica organización social es porque logran integrar y apaciguar el caos introducido por la chica moderna (sus cruces de clase, su autonomía, su verborragia). Sin embargo, en Muchachas que estudian, el cambio que proponen Ana e Isabel - el cuestionamiento de la pareja heterosexual sobre la que se basa el matrimonio y, por ende, la puesta en peligro de la institución familiar-es demasiado radical. Por eso la película no habilita la formación de un nuevo orden, sino la regresión al estado anterior a la aparición del conflicto. El relato abandona rápidamente el modo cómico con el que empezó y la condena melodramática se posa sobre los personajes. Aparecen los celos y las traiciones entre sus integrantes, incluso una joven de 15 años «da el mal paso» y queda embarazada en un episodio que no se muestra pero que sugiere una violación. En Mujeres que trabajan también hay rivalidades de este tipo, pero terminan triunfando los lazos de solidaridad femenina y la acción colectiva. En Muchachas que estudian, en cambio, la disolución de la comunidad femenina es total. Si finalmente el orden se restituye es porque las dos mujeres de convicciones más fuertes tuvieron que reconocer que estaban confundidas y retractarse. Ana abandona la ciencia y le hace una declaración de amor al colega que siempre estuvo enamorado de ella: «Todas hemos vivido hasta hoy en un mundo falso, creyendo pertenecer a otra humanidad superior. Y no somos otra cosa que mujeres, nada más que mujeres». Isabel le pide disculpas a su novio: «Perdóname, yo creía en la amistad, en el altruismo, en la lealtad de las mujeres, todas ilusiones y amargura. No hay más que el amor». La historia se cierra en la iglesia con la consumación de dos casamientos y la promesa de un tercero.

Ahora bien, esto no quiere decir que la comedia romántica de Romero se rinda totalmente ante la institución matrimonial. Incluso Muchachas que estudian, que se podría definir como una comedia de baja intensidad, una comedia punitiva o un híbrido en el cual el melodrama tiene un peso preponderante, se permite cierta ironía. Para contrarrestar la solemnidad de la última escena, Romero incluye un diálogo que matiza la supuesta potencia reformadora de la unión legal y religiosa. Cuando el novio de Ana le dice: «iQué efecto maravilloso produce la música del órgano! ¿No te emociona?». Ella no puede evitar devolver una respuesta cientificista en vez de una frase romántica: «Son las vibraciones sonoras que al reflejarse en las superficies cóncavas...». Él, espantado, no deja que termine la frase. Los finales de este tipo, y otros todavía más incisivos, son recurrentes en la screwball comedy. Si bien algunos críticos sostienen que es un género en última instancia conservador porque la boda del final soluciona mágicamente las diferencias, otras lecturas como la de Kathrina Glitre señalan lo contrario. No todas las películas terminan con un final reconciliador; de hecho, en la fundadora Sucedió una noche la protagonista se escapa de su propio casamiento hacia un lugar indeterminado, evadiendo el tópico de la «integración social». Y en aquellas ocasiones donde el relato sí culmina en una boda, este ritual está lejos de ser afirmativo; por el contrario, muchas veces socava el estatus de la institución matrimonial. ${ }^{48}$ El caso paradigmático es el final paródico de Un marido rico (The Palm Beach Story, Preston Sturges, 1942) que pone un manto de cinismo sobre la supuesta felicidad del matrimonio. La última escena es la imagen de un casamiento triple sobre la que se imprime el título: «Y vivieron felices para siempre». Pero en seguida aparece otro que dice: «¿O no?».
[47] María Paula Bontempo y Graciela Queirolo, «Las chicas modernas se emplean como dactilógrafas» (Bicentenario. Revista de Historia de Chile y América, vol. 11, $\mathrm{n}^{\circ} 2$, 2012), pp. 51-76, p. 58 .

[48] Kathrina Giltre, Hollywood Romantic Comedy: States of the Union, 1934-1965, p.43. 
[49] Sobre los finales irónicos o reflexivos de Schlieper véase María Valdez, «Sobre el arroz, la leche y la golosa resbaladera del sentido», en Arroz con leche. Edición Facsimilar del guion de Carlos Schlieper y Julio Porter (Buenos Aires, BAFICI, 2014); y Alejandro Kelly Hopfenblatt, Modernidad y teléfonos blancos. La comedia burguesa en el cine argentino de los años 40 (Buenos Aires, Ciccus, 2019).

[50] Esto no quiere decir que el divorcio no fuera un tema de discusión en el contexto nacional, tal como señala Dora Barrancos al analizar el debate parlamentario de 1932. Asimismo, la realidad no se ajustaba al moralismo discursivo y uno de los fenómenos más aludidos en el debate fue "el comercio del divorcio», es decir, la recurrencia con la que los argentinos cruzaban a Uruguay donde era legal desde 1907. Véase Dora Barrancos, Mujeres en la sociedad argentina. Una historia de cinco siglos (Buenos Aires, Sudamericana, 2007). Romero, siempre atento a las problemáticas del presente, incluyó esta práctica en Divorcio en Montevideo (1939).

[51] Stanley Cavell, La búsqueda de la felicidad. La comedia de enredo matrimonial en Hollywood (Barcelona, Paidós, ([1981] 1999), p. 93.
Claramente, en el caso de Romero no existe este grado de subversión (hay que esperar al cine de Carlos Schlieper de fines de los años cuarenta para ver algo similar) ${ }^{49}$ ya que sus giros cómicos raramente ponen en duda el final feliz, más bien acotan una suerte de disrupción pícara e inocente. Además, nunca están a cargo de la pareja protagonista sino de personajes secundarios que se prestan más fácilmente al ridículo (Niní Marshall, Enrique Serrano, Sofía Bozán, Tito Lusiardo). No obstante, en sus películas hay una interesante revisión de las condiciones de la institución matrimonial que sintoniza con uno de los grandes temas de la screwball comedy: la reformulación de la pareja heterosexual. Existe cierto consenso crítico e historiográfico en leer el surgimiento de este género como parte de una serie de cambios en la concepción del amor y el matrimonio en el período de entreguerras. La disminución de los casamientos, al aumento de los divorcios y la caída de la natalidad durante los años veinte, junto la redefinición de la sexualidad femenina en la sociedad de masas con la aparición de la flapper, la New Woman y la working girl, pusieron en crisis al matrimonio y a la pareja tradicionales en los Estados Unidos. La unión matrimonial ya no era concebida únicamente como una institución social y económica basada en el amor espiritual y en la moral victoriana, sino una unión basada en la compatibilidad emocional, la atracción sexual, el compañerismo y el ocio. La comedia romántica de los años treinta representó esta nueva concepción del amor y la unión conyugal, y tuvo como protagonista a una heroína que priorizaba sus deseos sobre los mandatos sociales demandando un matrimonio que apuntara hacia una relación de mayor igualdad. De allí que muchas de estas comedias fueran historias de rematrimonio (comedies of remarriage o comedias de enredo matrimonial según la traducción habitual) donde se pasa de un modelo de pareja antiguo a uno moderno.

Es interesante que, a pesar de la ilegalidad del divorcio en Argentina,${ }^{50}$ Romero se interesara por un género «que cambia la pregunta inicial de la comedia de si una joven pareja se casará por la pregunta de si la pareja se divorciará y permanecerá divorciada». ${ }^{51}$ Para evadir este problema recurrió a un simple desplazamiento: sus heroínas, en lugar de estar atadas a un matrimonio legal, generalmente tienen un prometido impuesto desde afuera con el que se niegan a casarse porque desean explorar otra forma de amor. Esto le permitió a Romero, sin alterar la esencia del género, adaptar la cuestión del amor moderno e igualitario que propone la screwball comedy y representar mujeres autónomas con las que las audiencias femeninas locales seguramente podían identificarse o fantasear. Sus chicas modernas abandonan a sus novios elegidos por imposición familiar, por afinidad de clase o por presión social, y los cambian por hombres con los que han atravesado un proceso de enamoramiento basado en momentos de compañerismo y felicidad. En La rubia del camino Betty descarta a sus dos candidatos —el conde decadente y el pretendiente mujeriego — por Julián, con quien experimentó un largo viaje en el cual se conocieron íntimamente. Al comienzo de Isabelita, Isabel sostiene que el matrimonio es una farsa y que los hombres son unos «idiotas», «necios», «engreídos», «incapaces de hacer la felicidad de una mujer» pero se va a casar porque «es un descrédito quedar para vestir santos en nuestra sociedad». Aun así, después de conocer a Luciano y de divertirse juntos (comen pizza, bailan, viajan en tranvía y van al cine, es decir: todas novedades para una chica acostumbrada a las tediosas visitas al teatro Colón con su prometido) el casamiento cobra otro significado. En Elvira Fernández el cambio de mentalidad generacional es todavía más claro, como analicé anteriormente; tanto Elvira como Luis coinciden en que un matrimonio arreglado no tiene sentido y deciden transitar una relación de 
amistad pese a las presiones del padre para concretar el casamiento. La amistad en este caso es más importante que el romance («somos más que novios, somos amigos» le dice ella). Los dos rompen el compromiso en buenos términos y se enamoran de un hombre y una mujer de la clase trabajadora.

Al ser romances interclasistas con la firma de Romero, podría argumentarse que esta nueva concepción sobre el amor y el matrimonio en las chicas modernas responde al contacto con la clase trabajadora antes que a una mayor autonomía del deseo femenino. No obstante, un buen contraejemplo es Mi amor eres tú, cuya historia se desarrolla plenamente en un ambiente burgués (los protagonistas son un abogado y una joven recién salida del colegio como pupila). Generalmente omitida en los estudios sobre su filmografía, quizás por la sobreidentificación de Romero con el mundo popular, esta película pone en el centro del relato dos visiones contrapuestas del matrimonio. Un modelo tradicional basado en intereses económicos, en la reproducción de cierto statu quo y en el aburrimiento, frente a un modelo moderno basado en una relación de amor auténtico, intimidad lúdica y un novedoso erotismo en la obra del director, antes escatimado debido a la rectitud moral que atribuía a sus personajes de extracción popular. Si

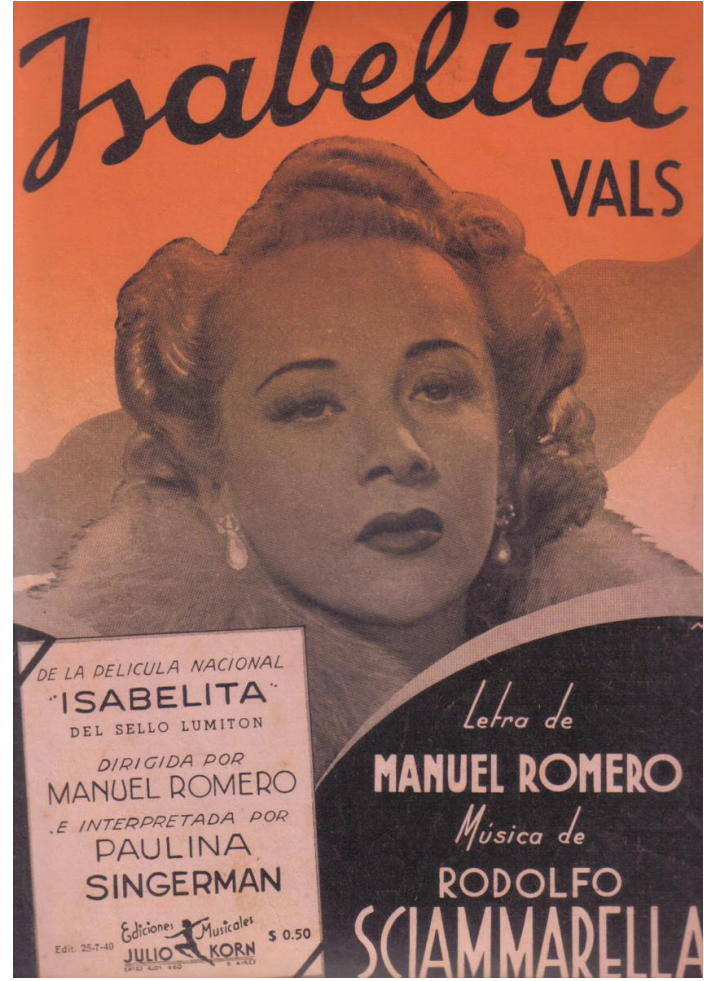

Afiche del vals de Isabelita. en La rubia del camino la mujer debía ser educada, en Mi amor eres tú, las lecciones paradójicamente no las dicta el protagonista masculino que hace de tutor, sino la chica moderna (otra vez Paulina Singerman) quien le enseña nuevas formas de vincularse.

Finalmente, la otra comedia burguesa que le permitió a Romero introducir una problemática femenina sin estar atado a la representación idealizada de la clase trabajadora fue Un bebé de París. Así como en Mi amor eres tú aparece una mujer más independiente con su sexualidad, en este caso se aborda el tema de la maternidad desde una perspectiva impensada considerando el antecedente de La rubia del camino donde la prosperidad de la pareja depende del surgimiento del instinto maternal en la chica moderna. Un bebé de París se pregunta qué sucede con ese mandato cuando la maternidad es biológicamente imposible debido a un problema de fertilidad, exponiendo al tipo de unión matrimonial cuya única razón de ser es la procreación. Lo sorprendente es que aquí Paulina Singerman encarna una esposa obediente y, a la vez, una de las versiones más extremas de la unruly woman. Y por ello, aunque en el núcleo de esta historia sobre un matrimonio en peligro hay tres tópicos típicos del melodrama — el amor imposible, la maternidad y la soledad de la mujer—, sería extraño definirla como tal. Romero filtra el drama que vive la mujer a través de la comedia y de la alocada protagonista dejando en evidencia las presiones sufridas bajo la «ideología del maternalismo». Sucede que, como afirma Rowe, «el exceso paródico de la unruly woman y los procedimientos cómicos que la rodean proveen un espacio para 'malinterpretar' los 'dilemas de la feminidad', para hacer risibles [...] los tropos de la feminidad valorizados por el melodrama». ${ }^{52}$

[52] Kathleen Rowe, The Unruly Woman, p. 11. 
Al ver a su marido alejarse, la protagonista se desespera y asume el mandato de ser madre a toda costa ( Yo no quiero perderlo, tengo que darle un hijo enseguida, tengo que ser madre»), pero esto desemboca en una escalada de situaciones delirantes: Raquel (Paulina Singerman) extorsiona al médico de la familia para que certifique un falso embarazo y luego finge demencia con el fin de ocultarse en un hospital psiquiátrico hasta conseguir un bebé ajeno y cumplir el sueño de su marido. ¿Pero qué sucede cuando Raquel, después de llevar la farsa hasta sus últimas consecuencias y después de vencer las limitaciones biológicas de su cuerpo para cumplir con el mandato familiar y social, espera un gesto de amor en su pareja y no encuentra reciprocidad? Al advertir que Atilio nunca estuvo interesado en ella, se produce un momento de reconocimiento y confrontación en el que desnuda el cinismo del esposo y la subestimación de su deseo:

ATILIO: Cómo me duele tu indiferencia para con el nene, Raquel. // RAQUEL: ¿Y la tuya para mí? Por lo visto como marido te consideras perfecto. Llegas del estudio, te pones la robe de chambre y a jugar con el nene. ‘Vamos al cine?'. 'No puedo, estoy cansado'. Pero no estás cansado para sentar al nene en tus rodillas y decirle mil pavadas [...] Siempre él, él... Yo no existo [...] Ya no siento tu mano sobre mi frente, ni el calor de tus labios. [...] ¡Sí! Estoy celosa y rabiosa contra él y contra ti y contra mi estúpida debilidad por habértelo dado. // A: ¡Cállate! // R: ¡No me da la gana! ¡Ve a mandar en tu oficina! No estoy muerta, mírame. Estoy frente a ti viva y palpitante. ¡Cuidado Atilio, cuidado! [...] A: Odia a su hijo, lo odia... Es espantoso.

\section{Conclusión}

Stanley Cavell —en La búsqueda de la felicidad, un libro fundacional y sumamente influyente en la crítica sobre la screwball comedy - sostiene que la estructura de la comedia romántica shakesperiana solo podía resurgir en 1934 y en Estados Unidos debido a la coincidencia de dos fenómenos interrelacionados: una nueva fase de la historia del cine, caracterizada por la aparición del sonido y el perfeccionamiento del uso del diálogo (central para este género dada la importancia de la conversación en el desarrollo de la pareja protagonista); y una nueva fase de la historia de la conciencia de la mujer que, después de la generación de sufragistas que consiguió el voto en 1920, expresó la necesidad de una actualización de las demandas de igualdad en el territorio doméstico. Cavell encuentra que las comedias de enredo matrimonial, a través de la conversación como vía ideal para la mediación de los conflictos, se hacen cargo de problemáticas complejas en torno al reconocimiento del deseo y la voz femeninos. Para el filósofo, como afirma Silvia Schwarzböck, «el cine de Hollywood pensó problemas que no habían sido pensados hasta el momento y tuvo un sujeto - la mujer - que había pasado desapercibido para otros saberes — con la excepción del psicoanálisis— $\gg .{ }^{53}$

No recupero estas ideas con el fin de trasladarlas al joven cine argentino de los años treinta, donde nunca existió una comedia de enredo matrimonial con ese grado de sofisticación y donde la comedia romántica en términos generales ni siquiera logró asentarse como un género, sino que lo que existió fue más bien un ciclo de películas - desparejo e híbrido - todas dirigidas por el mismo autor y protagonizadas en

[53] Silvia Schwarzböck, «Lejos de Harvard. Sobre la filosofía del cine de Stanley Cavell» (Kilómetro $\left.111, \mathrm{n}^{\circ} 7,2008\right)$, p. 35 . su mayoría por la misma actriz. Además, según analicé a lo largo del artículo, son muchas las diferencias tanto en la esfera social y política (en Argentina no había voto femenino ni ley de divorcio) como a nivel de los textos fílmicos (las expresiones lo- 
cales de la comedia romántica fallan en generar una disputa entre iguales; dependen excesivamente del melodrama; no pueden evitar el tópico de la maternidad; acotan el erotismo a acciones mínimas; raramente ponen en ridículo a los protagonistas masculinos; y sus finales casi no dejan espacio a la ambigüedad). Sin embargo, lo que me interesa de la propuesta de Cavell es la capacidad que le adjudica a las comedias para abordar de manera excepcional problemáticas complejas a través de un discurso común y (aunque Cavell no usa este concepto) de masas. Romero, a su manera y con los medios disponibles, adaptando o inspirándose en distintas variantes de la screwball comedy expuso en repetidas ocasiones distintas tensiones sociales y de género, incluso desde posiciones regresivas o conservadoras, no resueltas en la sociedad argentina de la primera mitad del siglo veinte.

Paulina Singerman, a quien Romero fue a buscar al teatro donde no casualmente había interpretado a la fierecilla indomable de la comedia shakesperiana (entre otros personajes similares), encarnó una y otra vez a una chica o mujer moderna cuya indocilidad se resiste a ser completamente controlada por el padre, el novio o el patrón. Pese a los finales más o menos conservadores (el destino del casamiento y/o de la maternidad), a lo largo del artículo intenté demostrar que la domesticación que suele atribuírsele a esta figura femenina en el ciclo de comedias romerianas nunca es total y, cuando parece inevitable, presenta múltiples ambigüedades. Claro que La rubia del camino no es la historia de emancipación femenina que puede leerse en Sucedió una noche, pero tampoco es la historia del puro sometimiento de la rica y extranjerizante Betty/Isabel en manos de Julián y la cultura popular nacional. En la íntima relación que establecen estas películas con la screwball comedy norteamericana, la joven moderna argentina - aun en su expresión local y moderada — es fundamentalmente disruptiva porque su aparición desestabiliza las estructuras sociales y, sobre todo, porque ella es quien expande la narración y crea las condiciones de posibilidad para que eso suceda. En este sentido, en el otro extremo del ciclo, es cierto que las mujeres de Elvira Fernández vuelven a sus puestos bajo las órdenes de los nuevos hombres de

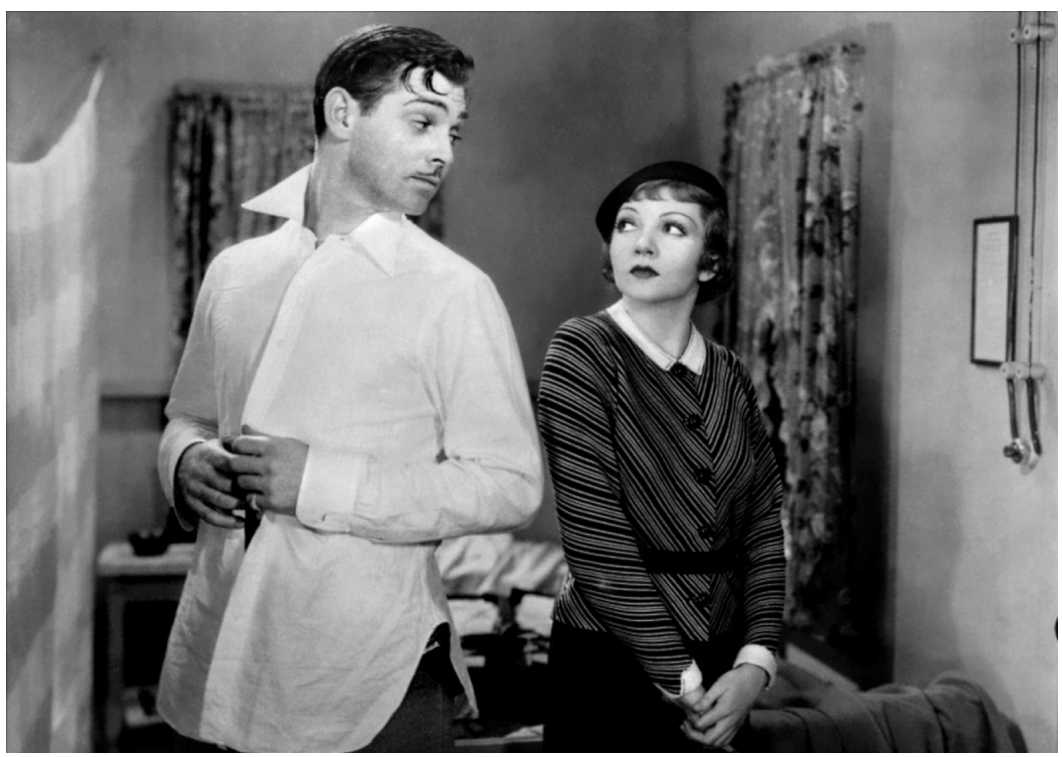

Clark Gable y Claudette Colbert en Sucedio una noche (Frank Capra, 1934). 
la empresa, pero el levantamiento de las vendedoras deja en claro que hay un límite que ya no admite ser violado o las consecuencias, como lo demostraron, pueden quebrar la paz social. El catalizador es, una vez más, la joven moderna que vino de Estados Unidos. Y la estructura narrativa que da lugar al cambio proviene de una película de Hollywood.

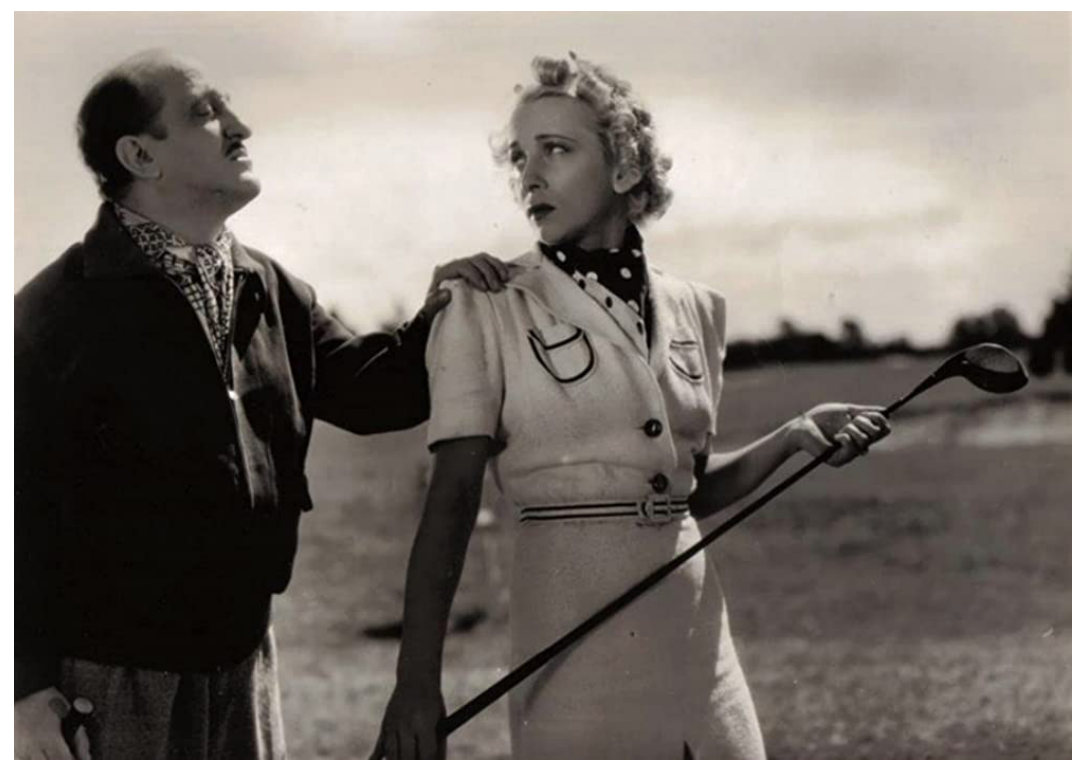

Paulina Singerman y Enrique Serrano en La rubia del camino (Manuel Romero, 1938).

En el cine argentino (y la sociedad argentina) de los años treinta, donde el melodrama maternal (y el mandato de maternidad) tiene una presencia determinante, así como la demanda de autenticidad nacional resulta ineludible, Romero abre un nuevo universo con estas comedias. Sus protagonistas introducen un pequeño pero inédito caos persiguiendo el deseo de independencia e imaginando una nueva forma de pareja amorosa, gracias al marco que les provee la comedia romántica internacional.

\section{BIBLIOGRAFÍA}

Armus, Diego, «El viaje al Centro. Tísicas, costureritas y milonguitas en Buenos Aires, 1910-1940» (Boletín del Instituto de Historia Argentina y Americana Dr. Emilio Ravignani, vol. 3, $\mathrm{n}^{\circ}$ 22, 2000), pp. 101-124.

BALlent, Anahí y GoRelik, Adrián, «País urbano o país rural: La modernización territorial y la crisis», en Alejandro Cataruzza (dir.), Crisis económica, avance del Estado e incertidumbre politica (1930-1943) (Buenos Aires, Sudamericana, 2001), pp. 143-200.

BARRAncos, Dora, Mujeres en la sociedad argentina. Una historia de cinco siglos (Buenos Aires, Sudamericana, 2007).

Bontempo, María Paula y Queirolo, Graciela, «Las chicas modernas se emplean como dactilógrafas» (Bicentenario. Revista de Historia de Chile y América, vol. $\left.11, \mathrm{n}^{\circ} 2,2012\right)$, pp. 51-76.

CAPrA, Frank, The Name above the Title (Nueva York, Macmillan, 1971). 
Cavell, Stanley, La búsqueda de la felicidad. La comedia de enredo matrimonial en Hollywood (Barcelona, Paidós, ([1981] 1999).

FrYe, Northrop, «The Argument of Comedy», en Paul Lauter (ed.), Theories of Comedy (Nueva York, Anchor, [1948] 1964), pp. 450-460.

Gil Mariño, Cecilia, «Una industria de "lo nuestro". Gestos antiimperialistas en el proceso de nacionalización de los cines argentino y brasileño en los primeros años del sonoro» (Foros del Programa Interuniversitario de Historia Politica, $\mathrm{n}^{\mathrm{o}}$ 6, 2017). Disponible en: <http://www.historiapolitica.com> (10/08/2020).

Giltre, Kathrina, Hollywood Romantic Comedy: States of the Union, 1934-1965 (Manchester, Manchester University Press, 2006).

Karush, Matthew, Cultura de clase. Radio y cine en la creación de una Argentina dividida (1920-1946) (Buenos Aires, Ariel, 2013).

Kelly Hopfenblatt, Alejandro, Modernidad y teléfonos blancos. La comedia burguesa en el cine argentino de los años 40 (Buenos Aires, Ciccus, 2019).

Lent, Tina Olsen, «Romantic Love and Friendship: The Redefinition of Gender Relations in Screwball Comedy», en Kristine Brunovska Karnick y Henry Jenkins (eds.), Classical Hollywood Comedy (Nueva York, American Film Institute, 1995), pp. 314- 331.

Lовато, Mirta Zaida, Historia de las trabajadoras en la Argentina (1869-1960) (Buenos Aires, Edhasa, 2007).

Mizejewski, Linda, It Happened One Night (Malden, Wiley-Blackwell, 2010).

Montaldo, Graciela, Museo del consumo. Archivos de la cultura de masas en Argentina (Buenos Aires, Fondo de Cultura Económica, 2016).

Morgenfeld, Leandro, Vecinos en conflicto. Argentina y Estados Unidos en las Conferencias Panamericanas (1880-1955) (Buenos Aires, Continente, 2011).

NARI, Marcela, Políticas de maternidad y maternalismo político. Buenos Aires, 18901940 (Buenos Aires, Biblos, 2004).

QueIrolo, Graciela, «Vendedoras: género y trabajo en el sector comercial (Buenos Aires, 1910-1950)» (Estudos Feministas, vol. 22, n 1, 2014), pp. 29-50.

Quinziano, Pascual, «La comedia. Un género impuro», en Sergio Wolf (comp.), Cine Argentino. La otra historia (Buenos Aires, Ediciones Letra Buena, 1992), pp. 129-146.

Rogin, Michael, «How the Working Class Saved Capitalism: The New Labor History and The Devil and Miss Jones» (The Journal of American History, 89:1, 2002), pp. 87-114.

Rowe, Kathleen, The Unruly Woman: Gender and the Genres of Laughter (Austin, University of Texas Press, 1995).

Schwarzböck, Silvia, «Lejos de Harvard. Sobre la filosofía del cine de Stanley Cavell» (Kilometro 111, n 7, 2008), pp. 9-36.

Sikov, Ed, Screwball: Hollywood's Madcap Romantic Comedies (Nueva York, Crown Publishers, 1989).

Tossounian, Cecilia, «The Argentine Modern Girl and National Identity, Buenos Aires, 1920-40», en Cheryl Lynn Krasnick Warsh y Dan Malleck (eds.). Consuming Modernity: Gendered Behaviour and Consumerism before the Baby Boom (Vancouver, UBC Press, 2013).

Tossounian, Cecilia, La Joven Moderna in Interwar Argentina: Gender, Nation, and Popular Culture (Gainesville, University of Florida Press, 2020).

VALdeZ, María, «El reino de la comedia: un terreno escurridizo y ambiguo», en 
Claudio España (dir.), Cine Argentino. Industria y clasicismo. Volumen II (Buenos Aires, FNA, 2000), pp. 270- 345.

VALDEZ, María, «Sobre el arroz, la leche y la golosa resbaladera del sentido», en Arroz con leche. Edición Facsimilar del guion de Carlos Schlieper y Julio Porter (Buenos Aires, BAFICI, 2014), pp. 19-29.

Recibido: 3 de noviembre de 2020

Aceptado para revisión por pares: 19 de enero de 2021

Aceptado para publicación: 9 de junio de 2021 
